\title{
Tat 101-Mediated Enhancement of Brain Pericyte Migration Involves Platelet-Derived Growth Factor Subunit B Homodimer: Implications for Human Immunodeficiency Virus-Associated Neurocognitive Disorders
}

\author{
굴ang Niu, ${ }^{1}$ Honghong Yao, ${ }^{2}$ - Wenting Zhang, ${ }^{1}$ Roy Lee Sutliff, ${ }^{3}$ and Shilpa Buch ${ }^{1}$ \\ ${ }^{1}$ Department of Pharmacology and Experimental Neuroscience, University of Nebraska Medical Center, Omaha, Nebraska 68198, ${ }^{2}$ Department of \\ Pharmacology, Medical School of Southeast University, Nanjing, China, 210009, and ${ }^{3}$ Department of Medicine, Emory University/Atlanta Veterans Affairs \\ Medical Center, Atlanta, Georgia 30033
}

In the era of antiretroviral therapy, although the human immunodeficiency virus (HIV) replication can be successfully controlled, complications of the CNS continue to affect infected individuals. Viral Tat protein is not only neurotoxic but has also been shown to disrupt the integrity of the blood-brain barrier (BBB). Although the role of brain microvascular endothelial cells and astrocytes in Tat-mediated impairment has been well documented, pericytes, which are important constituents of the BBB and play a key role in maintaining the integrity of the barrier, remain poorly studied in the context of HIV-associated neurocognitive disorders (HAND). In the present study, we demonstrated that exposure of human brain microvascular pericytes and C3H/10T1/2 cells to HIV-1 Tat101 resulted in increased expression of platelet-derived growth factor subunit B homodimer (PDGF-BB) and increased migration of the treated cells. Furthermore, we also demonstrated that this effect of Tat was mediated via activation of mitogen-activated protein kinases and nuclear factor- $\kappa$ B pathways. Secreted PDGF-BB resulted in autocrine activation of the PDGF-BB/PDGF $\beta$ receptor signaling pathway, culminating ultimately into increased pericyte migration. Ex vivo relevance of these findings was further corroborated in isolated microvessels of HIV Tg26 mice that demonstrated significantly increased expression of PDGF-BB in isolated brain microvessels with a concomitant loss of pericytes. Intriguingly, loss of pericyte coverage was also detected in sections of frontal cortex from humans with HIV-encephalitis compared with the uninfected controls. These findings thus implicate a novel role of PDGF-BB in the migration of pericytes, resulting in loss of pericyte coverage from the endothelium with a subsequent breach of the BBB.

Key words: BBB; HIV Tat; PDGF-BB; pericytes

\section{Introduction}

The cerebrovascular unit of the blood-brain barrier (BBB) consists of endothelial cells, astrocytes, and pericytes, which cooperatively maintain a tight barrier that is impermeable to toxic agents, ions, and pathogens, thereby maintaining homeostasis and keeping the brain as an immunoprivileged organ. One of the pivotal mechanisms leading to neuroinflammation associated with human immunodeficiency virus type $1(\mathrm{HIV}-1)$ infection of

\footnotetext{
Received March 20, 2014; revised June 12, 2014; accepted July 15, 2014.

Author contributions: F.N., H.Y., and S.B. designed research; F.N. and W.Z. performed research; R.L.S. contributed unpublished reagents/analytic tools; F.N. analyzed data; F.N., H.Y., and S.B. wrote the paper.

This work was supported by National Institutes of Health Grants DA033150, DA033614, DA035203, and DA036157 (SB). We thank Novartis for providing us with STI-571. We also thank Dr. Young Han Lee (Konkuk University, Seoul, Korea) for providing the dominant-negative and constitutively active constructs of MEK and Roy L. Sutliff (Emory University/Atlanta Veterans Affairs Medical Center, Atlanta, GA) for providing us with HIV Tg26 and WT mice.

The authors declare no competing financial interests.

Correspondence should be addressed to Dr. Shilpa J. Buch, Department of Pharmacology and Experimental Neuroscience, 985880 Nebraska Medical Center (DRC 8011), University of Nebraska Medical Center, Omaha, NE 68198-5880. E-mail: sbuch@unmc.edu.

DOI:10.1523/JNEUROSCI.1139-14.2014

Copyright $\odot 2014$ the authors $\quad 0270-6474 / 14 / 3411812-14 \$ 15.00 / 0$
}

the CNS involves breach of the BBB, resulting in influx of inflammatory cells in the CNS with ensuing neurological complications. Although the roles of endothelial cells and astrocytes in BBB dysfunction in the context of HIV proteins (Tat and Gp120) have been well studied (Kim et al., 2003; Toborek et al., 2003; Zhou et al., 2004; Ricardo-Dukelow et al., 2007; Hsue et al., 2009; Masiá et al., 2010; McArthur et al., 2010; Bethel-Brown et al., 2012; Xu et al., 2012; Zhong et al., 2012), the function of pericytes, one of the understudied but important cell types of the cerebrovascular unit, remains poorly understood.

Pericytes are uniquely positioned within the brain microvascular and play an integral role in the development and maintenance of the cerebrovascular unit (Bell et al., 2010). These cells are known to function as integrators, coordinators, and effectors of the $\mathrm{BBB}$, which in turn regulates permeability of the barrier, the cerebral blood flow, and toxic product clearance (Winkler et al., 2011). Loss of pericytes resulting in disruption of the BBB has been observed in several pathologies in animal models (Shah et al., 2013; Zechariah et al., 2013). Furthermore, platelet-derived growth factor subunit $\mathrm{B}$ homodimer (PDGF-BB) signaling through its cognate PDGF $\beta$ receptor (PDGFR $\beta$ ) is essential for 
Table 1. Clinical data for human brain tissue samples

\begin{tabular}{|c|c|c|c|c|c|c|c|}
\hline Case number & HIV-1 infection & Age (years) & Gender & Viral load (plasma) & Neurocognitive assessment & Antiretroviral therapy & Pathology \\
\hline $1(3015)$ & Negative & 64 & Female & NA & $\begin{array}{l}\text { Neuropsychological impairment } \\
\text { or dementia attributable to } \\
\text { another cause }\end{array}$ & None & $\mathrm{HIV}^{-}, \mathrm{PML}$ \\
\hline $2(7101958083)$ & Negative & 46 & Male & NA & $\begin{array}{l}\text { Unable to reliably assign neuro- } \\
\text { cognitive diagnosis }\end{array}$ & None & $\mathrm{HIV}^{-}$ \\
\hline $3(7102308387)$ & Negative & 49 & Male & NA & $\begin{array}{l}\text { Unable to reliably assign neuro- } \\
\text { cognitive diagnosis }\end{array}$ & None & $\mathrm{HIV}^{-}$ \\
\hline $4(4084)$ & HIV-E & 46 & Male & 40,519 & $\begin{array}{l}\text { Neuropsychological impairment } \\
\text { or dementia attributable to } \\
\text { another cause }\end{array}$ & None & $\begin{array}{l}\text { HIV-E, Alzheimer type } \\
2 \text { gliosis }\end{array}$ \\
\hline $5(5007)$ & HIV-E & 37 & Female & 750,000 & Possible HAND & TFV, ddl, KTA & $\begin{array}{l}\text { HIV-E, Alzheimer type } \\
2 \text { gliosis }\end{array}$ \\
\hline $6(4151)$ & HIV-E & 58 & Male & 4,064 & Possible HAND & $\begin{array}{c}\text { TFV, RTV, DAR, KTA, TZV, } \\
\text { ATV, TRU, ATR, ETC }\end{array}$ & $\begin{array}{l}\text { HIV-E, Alzheimer type } \\
2 \text { gliosis }\end{array}$ \\
\hline
\end{tabular}

ATR, Atripla; ATV, atazanavir; DAR, darunavir; ddl, didanosine; ETC, emtricitabine; KTA, Kaletra; PML, progressive multifocal leukoencephalopathy; RTV, ritonavir; TFV, tenofovir; TRU, Truvada; TZV, Trizivir.

pericyte generation, and mice knocked down for either the ligand or its receptor demonstrate a complete loss of pericyte coverage (Lindahl et al., 1997) and exhibit endothelial hyperplasia and increased vascular permeability (Hosaka et al., 2013).

In recent years, the role of pericytes in HIV-associated neurocognitive disorders (HAND) has been gaining attention. For example, recent findings by Nakagawa et al. (2012) demonstrate that pericytes are capable of being infected by HIV-1, thereby implicating the role of these cells in the progression of HIVinduced damage of the CNS. Similar to glial activation by inflammatory agents, pericytes have also been shown to be activated in response to lipopolysaccharide (LPS), leading in turn to release of mediators that aid in promoting transcytosis of HIV-1 virus across the BBB (Dohgu and Banks, 2013). Because HIV proteins such as Tat are present in the host despite suppression of virus replication in treated individuals and because Tat is known to induce expression of cerebrovascular permeants such as PDGF (Bethel-Brown et al., 2011; Bethel-Brown et al., 2012), we sought to examine the modulation of PDGF-BB in pericytes exposed to HIV-1 Tat and, subsequently, to examine how this modulation affected pericyte functioning. Herein, cell culture findings were also validated ex vivo in both an HIV-1 transgenic mouse model (Dickie et al., 1991) and sections of the frontal cortex from humans with HIV-encephalitis (HIV-E). These findings could have clinical implications in the development of therapeutic strategies aimed at restoring the $\mathrm{BBB}$ breach in patients with HANDs.

\section{Materials and Methods}

Animals. HIV-1 transgenic mice (Tg26), which express high levels of HIV protein, such as Tat, rev, nef, vif, vpr, and $v p u$, were established using the $7.4 \mathrm{~kb}$ transgene construct lacking the $3 \mathrm{~kb}$ sequence overlapping the gag/pol region of provirus pNL4-3 (Mouse Genome Informatics identification number 3771187) as described previously (Kopp et al., 1992). $\mathrm{Tg} 26$ mice in the FVB/ $\mathrm{N}$ background were backcrossed eight generations to a C57BL/6 background by Dr. Roy L. Sutliff (Veterans Affairs Medical Center, Atlanta, GA). Wild-type (WT) mice generated from the same litter of Tg26 mice were used as controls for these studies. All animals were housed under conditions of constant temperature and humidity on a $12 \mathrm{~h}$ light/dark cycle, with lights on at 7:00 AM. Food and water were available ad libitum. Animals of either sex were deeply anesthetized by an overdose of isoflurane, followed by pneumothorax before perfusion. All animal procedures were performed according to the protocols approved by the Institutional Animal Care and Use Committee of the University of Nebraska Medical Center and the National Institutes of Health.

Cell culture. Primary human brain vascular pericytes (HBVPs) were purchased from ScienCell and cultured in the pericyte medium (Scien-
Cell). Cell culture dishes were coated with poly-L-lysine $\left(2 \mu \mathrm{g} / \mathrm{cm}^{2}\right)$ and were used in passages $2-5$. Pericyte cell line $\mathrm{C} 3 \mathrm{H} / 10 \mathrm{~T} 1 / 2$, clone 8 cell line was purchased from American Type Culture Collection (catalog \#CCL226). Cells were cultured with MEM (Gibco) containing 10\% heatinactivated fetal bovine serum, penicillin $(100 \mathrm{U} / \mathrm{ml})$, streptomycin $(100$ $\mu \mathrm{g} / \mathrm{ml}$ ), and $2 \%$ sodium bicarbonate solution (Gibco) and were used for passages 4-14.

Reagents. Recombinant Tat 101 was purchased from ImmunoDiagnostics. Recombinant PDGF-BB and the specific mitogen-activated protein (MAP) kinase kinase 1/2 (MEK1/2) inhibitor U0126 [1,4diamino-2,3-dicyano-1,4-bis (o-aminophenylmercapto)butadiene] were purchased from R\&D Systems. Mouse neutralizing PDGF-BB antibody and the IgG control antibody were purchased from Abcam. Inhibitor specific for p38 (SB203580 [4-(4-fluorophenyl)-2-(4-methylsulfinylphenyl)-5-(4-pyridyl)-1 $H$-imidazole]) was purchased from Andwin Scientific, for phosphoinositide 3-kinase (PI3K) (LY294002 [2(4-morpholinyl)-8-phenyl-1(4H)-benzopyran-4-one]) was purchased from Cayman Chemical, and for Janus kinase (JNK) inhibitor II [SP600125 (anthra[1,9-cd]pyrazol-6(2H)-one)] was purchased from EMD Chemical Millipore. PDGFR Tyrosine kinase inhibitor STI571 (4[(4-methylpiperazin-1-yl)methyl]-N-[4-methyl-3-[(4-pyridin-3-ylpyrimidin-2-yl)amino]phenyl]benzamide) was obtained from Novartis. CellTracker Green CMFDA (5-chloromethylfluorescein diacetate) was purchased from Invitrogen. The primary antibodies used included the following: phosphorylated extracellular signal-regulated protein kinase (p-ERK)/ERK, p-JNK/JNK, p-p38/p38, p-Akt/Akt, p-nuclear factor- $\kappa$ B inhibitor $(\mathrm{I} \kappa \mathrm{B}-\alpha) / \mathrm{I} \kappa \mathrm{B}-\alpha$, and $\mathrm{p}-\mathrm{PDGFR}-\beta$ were purchased from Cell Signaling Technology; HIV Tat, cluster of differentiation 31 (CD31), nuclear factor $-\kappa \mathrm{B}(\mathrm{NF}-\kappa \mathrm{B})$, PDGF-BB (mouse/rabbit), and PDGFR- $\beta$ antibody were obtained from Abcam; NG2 and 4G10 antibody was purchased from Millipore; GAPDH and Lamin B were purchased from Santa Cruz Biotechnology; $\beta$-actin was purchased from Sigma-Aldrich. The secondary antibodies were alkaline phosphatase conjugated to goat antimouse/rabbit IgG or rabbit anti-goat IgG (Jackson ImmunoResearch).

Boyden chamber migration assay. A Boyden chamber (Corning Costar) was used to determine the migration of pericytes in vitro as described previously (Yao et al., 2013). Briefly, cells were fluorescently labeled with $10 \mu \mathrm{M}$ cell tracker green for $10 \mathrm{~min}$ at $37^{\circ} \mathrm{C}$. Labeled cells $\left(1 \times 10^{6}\right.$ cells $/ \mathrm{ml}$ ) were added to the upper compartment of transwell inserts in serum-free medium with different treatments in both sides of the chamber. The transwell plates were incubated for $18 \mathrm{~h}$ at $37^{\circ} \mathrm{C}$, followed by quantification of pericyte migration by measuring the number of migrated cells after detachment of cells from the insert using a Synergy Mx fluorescence plate reader (BioTek Instruments).

Wound-healing assay. The other method to detect pericyte migration involved the CytoSelect Wound Healing Assay Kit (Cell Biolabs) according to the instructions of the manufacturer. Briefly, $600 \mu \mathrm{l}$ of cell suspension containing $\mathrm{C} 3 \mathrm{H} / 10 \mathrm{~T} 1 / 2\left(3 \times 10^{5}\right.$ cells $\left./ \mathrm{ml}\right)$ or HBVP 
$\left(4 \times 10^{5}\right.$ cells $\left./ \mathrm{ml}\right)$ was plated to form the monolayer within the wound field. The cells were treated for $18 \mathrm{~h}$ and monitored for migration after stopping the reaction by staining buffer and subsequently photographed using the Olympus DP71 microscope. Statistical data on the percentage of migrated cells was done using the Tscratch software (Geback et al., 2009).

Reverse transcription and real-time PCR. The conditions for reverse transcription (RT) and real-time PCR assays have been described previously (Yao et al., 2011a). Real-Time PCR primers for mouse PDGF-A, PDGF-B, PDGF-C, and $18 \mathrm{~S}$ were obtained from SA Biosciences. Total RNA was extracted with TRIzol reagent (Invitrogen) according to the instructions of the manufacturer. Quantitative analyses of mRNA were conducted using ABI 7500 Fast Real-Time PCR system (Applied Biosystems). Amplifications were performed for 40 cycles (denaturation, $30 \mathrm{~s}$ at $95^{\circ} \mathrm{C}$; annealing, 1 min at $60^{\circ} \mathrm{C}$ ).

Short-interfering RNA and plasmid transfection. $\mathrm{C} 3 \mathrm{H} / 10 \mathrm{~T} 1 / 2$ cells were transfected with short-interfering RNA (siRNA) of PDGFR- $\beta$ (Thermo Fisher Scientific) and also with plasmid constructs containing either WT or dominant-negative (DN) MEK or I $\kappa \mathrm{B}$ overexpressing (OE) constructs. The knockdown efficiency of siRNAs was determined $1 \mathrm{~d}$ after transfection using Western blot.

Western blot. Treated cells or isolated microvessels were lysed using the Mammalian Cell Lysis kit (Sigma-Aldrich) as described previously (Yao et al., 2011a). Equal amounts of the proteins were electrophoresed in a SDSpolyacrylamide gel (12\%) under reducing conditions, followed by transfer to PVDF membranes. The blots were blocked with 5\% bovine serum albumin in TBST (TBS and Tween 20). Western blots were probed with antibodies recognizing p-ERK/ERK [Cell Signaling Technology; catalog \#9101S/9107S; Research Resource Identifier (RRID): $\mathrm{AB}_{-}$ 331646/AB_10695739], p-JNK/JNK (Cell Signaling Technology; catalog \#9251S/9252S; RRID: AB_331659/AB_10693936), p-p38/p38 (Cell Signaling Technology; catalog \#9211S/ 9212S; RRID: AB_331640/AB_10695667), p-Akt/Akt (Cell Signaling Technology; catalog \#9271S/9272S; RRID: AB_329825/ AB_10699016), p-I $\kappa$ B- $\alpha / \mathrm{I} \kappa \mathrm{B}-\alpha$ (Cell Signaling Technology; catalog \#2859S/4812S; RRID: AB_561111/AB_10694416), p-PDGFR- $\beta$ (Cell Signaling Technology; catalog \#3161S; RRID: AB_331053), PDGFR- $\beta$ (Abcam; catalog \#ab32570; RRID: AB_777165), NF- $\kappa$ B (Abcam; catalog \#ab16502; RRID: AB_443394), PDGF-BB (Abcam; catalog \#ab23914; RRID: AB_2162180), Lamin B (Santa Cruz Biotechnology; catalog \#SC6216; RRID: AB_648156), GAPDH (Santa Cruz Biotechnology; catalog \#sc-32233; RRID: AB_627679) at 1:1000 dilution, NG2 (Millipore; catalog \#ab5320; RRID: AB_11213678) and HIV Tat (Abcam; catalog \#ab24778; RRID:AB_448314) at 1:500 dilution, and $\beta$-actin (Sigma-Aldrich; catalog \#A1978; RRID: AB_476692) at 1:5000 dilution. Signals were detected by chemiluminescence (Pierce). All experiments were repeated four times individually, and representative blots are presented in the figures.

Immunoprecipitation. Immunoprecipitation was performed as described previously (Yao et al., 2011b). C3H/10T1/2 cells were treated
$\mathrm{C} 3 \mathrm{H} / 10 \mathrm{~T} 1 / 2$

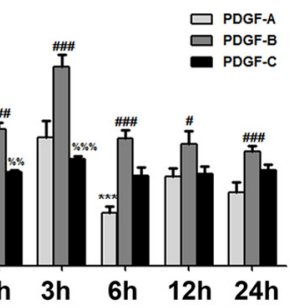

B

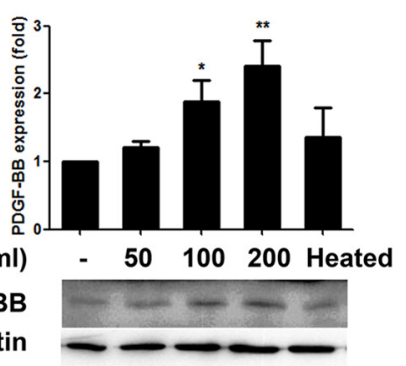

HBVP

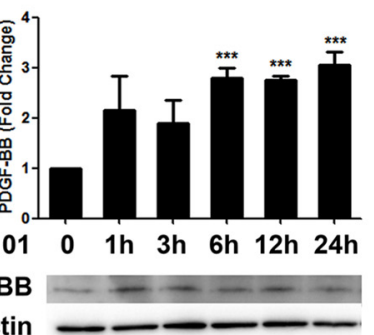

$\mathrm{C} 3 \mathrm{H} / 10 \mathrm{~T} 1 / 2$

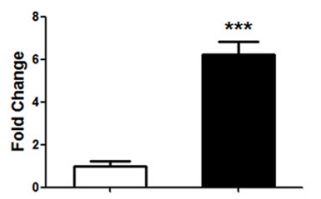

HBVP

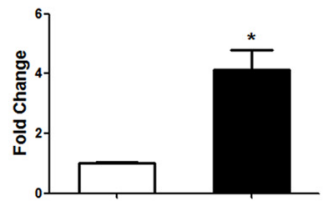

Figure 1. Tat101 mediated upregulation of PDGF-BB in both C3H/10T1/2 cells and HBVPs. $A$, Real-time PCR analysis of PDGF-A, PDGF-B, and PDGF-C chain mRNA expression in C3H/10T1/2 cells treated for varying time points with Tat101 (200 ng/ml). Tat101 response at $200 \mathrm{ng} / \mathrm{ml}$. C, Tat101-mediated time-dependent induction of PDGF-BB expression in C3H/10T1/2 cells and HBVPs. 10T1/2 cells $(\boldsymbol{D})$ and HBVPs $(\boldsymbol{E})$ were treated with Tat101 for $24 \mathrm{~h}$ and stained with antibodies specific for PDGF-BB. Overlay 作 versus the control (Con) group (Student's $t$ test).

with Tat101 (200 ng/ml) for varying times and then lysed using the Mammalian Cell Lysis kit (Sigma-Aldrich). For each sample, $150 \mu \mathrm{g}$ of protein was used for immunoprecipitation. Cell lysates were incubated with $1 \mu \mathrm{l}$ of anti-4G10 antibody (Millipore; catalog \#ab5320; RRID: $\left.\mathrm{AB} \_11213678\right)$ overnight at $4^{\circ} \mathrm{C}$, followed by incubation with $30 \mu \mathrm{l}$ of protein A Sepharose CL-4B (GE Healthcare) for $1.5 \mathrm{~h}$ at $4^{\circ} \mathrm{C}$. The mixture was then centrifuged at 12,000 rpm for $1 \mathrm{~min}$, and the cell pellets were rinsed twice with the lysis buffer (1.0\% NP-40, 0.5\% sodium deoxycholate, $0.1 \%$ SDS, $150 \mathrm{~mm} \mathrm{NaCl}, 9.1 \mathrm{~mm} \mathrm{Na}_{2} \mathrm{HPO}_{4}$, and $1.7 \mathrm{~mm}$ $\mathrm{NaH}_{2} \mathrm{PO}_{4}$ ) containing proteinase and phosphatase inhibitors. Finally, 30 $\mu \mathrm{l}$ of $2 \times$ Western blot loading buffer was added and boiled for $5 \mathrm{~min}$. After spinning at 12,000 rpm for $1 \mathrm{~min}$, the supernatants were subjected to Western blot analysis as described above.

Isolation of brain microvessels. Brain microvessels were isolated as described previously (Yao et al., 2011a). Briefly, the brains were removed 
A

Tat101(ng/ml)

0

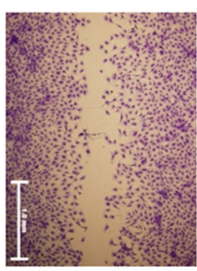

$\mathrm{C} 3 \mathrm{H} / 10 \mathrm{~T} 1 / 2$

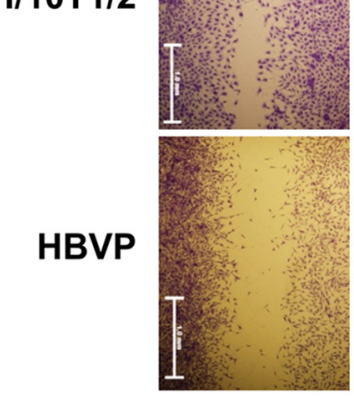

B

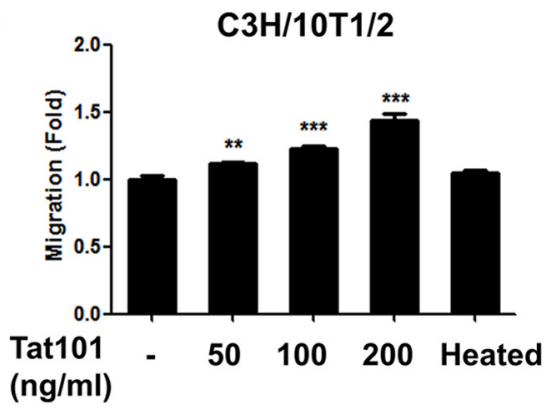

50

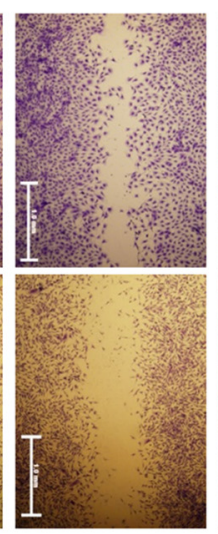

100
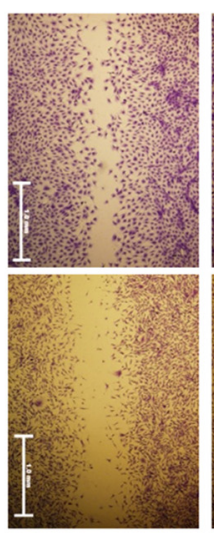

200
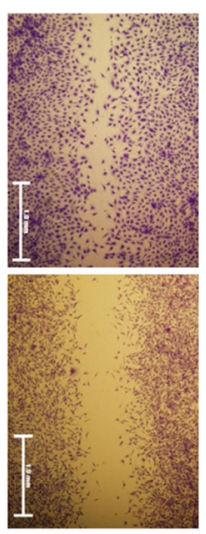

Heated

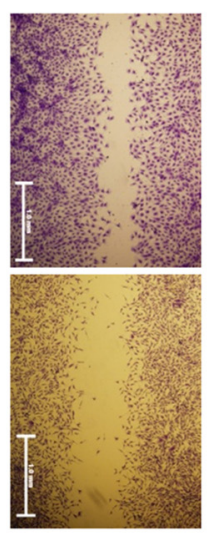

C

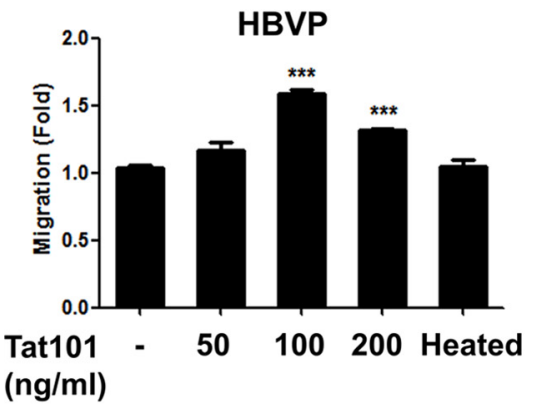

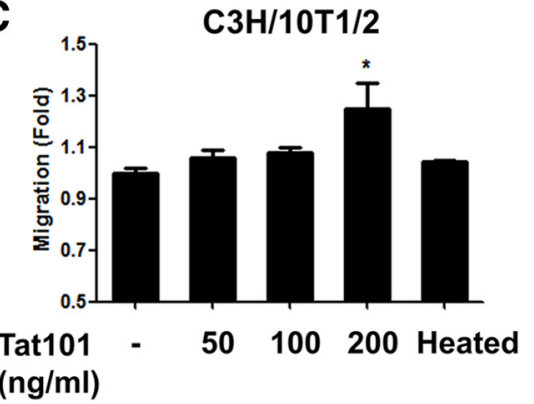

Figure 2. Tat101 induces pericyte migration. $A$, Tat101 induced $\mathrm{C} 3 \mathrm{H} / 10 \mathrm{~T} 1 / 2$ cell and HBVP migration in a concentration-dependent manner using the wound-healing assay, whereas heated Tat101 had no effect. Scale bars, $1.0 \mathrm{~mm}$. B , The wound-healing assay was analyzed by Tscratch software and showed concentration-dependent migration of C $3 \mathrm{H} / 10 \mathrm{~T} 1 / 2$ and HBVPs in response to Tat101, with heated Tat exerting no effect on migration. $C$, Tat101-mediated migration of $\mathrm{C} 3 \mathrm{H} / 10 \mathrm{~T} 1 / 2$ cells was concentration dependent as measured by Boyden chamber migration assay, with maximal response observed at a concentration of $200 \mathrm{ng} / \mathrm{ml}$. All data are presented as mean \pm SD of four individual experiments. ${ }^{*} p<0.05,{ }^{* *} p<0.01,{ }^{* * *} p<0.001$ versus the Con group (Student's $t$ test).

and immediately immersed in ice-cold isolation buffer A (in mM: 103 $\mathrm{NaCl}, 4.7 \mathrm{KCl}, 2.5 \mathrm{CaCl}_{2}, 1.2 \mathrm{KH}_{2} \mathrm{PO}_{4}, 1.2 \mathrm{MgSO}_{4}$, and 15 HEPES, $\mathrm{pH}$ 7.4). The choroid plexus, meninges, cerebellum, and brainstem were removed, followed by homogenization of the brain in $2.5 \mathrm{ml}$ of isolation buffer B ( $25 \mathrm{~mm} \mathrm{NaHCO}_{3}, 10 \mathrm{~mm}$ glucose, $1 \mathrm{~mm} \mathrm{Na}^{+}$pyruvate, and 10 $\mathrm{g} / \mathrm{L}$ dextran, $\mathrm{pH}$ 7.4) with complete protease inhibitors. Dextran (6 ml; $26 \%$ ) was then added to the homogenates, followed by centrifugation at $5800 \times g$ for $20 \mathrm{~min}$. Cell pellets were resuspended in isolation buffer $\mathrm{B}$ and filtered through a $70 \mu \mathrm{m}$ mesh filter (BD Biosciences). Filtered homogenates were repelleted by centrifugation, and part of it was used for staining by smearing on glass slides, and the other portion was lysed for Western blotting.

Immunofluorescence staining. Brain microvessels smeared on glass slides and pericytes (HBVP and $\mathrm{C} 3 \mathrm{H} / 10 \mathrm{~T} 1 / 2$ ) cultured on coverslips were fixed with $4 \%$ formaldehyde in PBS for $20 \mathrm{~min}$ at room temperature (RT). The slides or coverslips were washed three times with PBS, permeabilized with $0.3 \%$ Triton X-100 for $30 \mathrm{~min}$, rewashed three times, and blocked in $10 \%$ goat serum in PBS for $2 \mathrm{~h}$ at RT. The following antibodies were used for immunostaining: mouse HIV Tat antibodies (Abcam; catalog \#ab24778; RRID:AB_448314; 1:100), rabbit NG2 antibodies (Millipore; catalog \#ab5320; RRID:AB_11213678; 1:200), mouse CD31 antibodies (Abcam; catalog \#ab24590; RRID:AB_448167; 1:100), mouse PDGF-BB antibodies (Abcam; catalog \#ab51869; RRID:AB_2299427; $1: 100$ ), and rabbit PDGFR- $\beta$ antibodies (Abcam; catalog \#ab32570; RRID:AB_777165; 1:100). The slides or coverslips were washed with PBS and incubated with Alexa Fluor 594-conjugated anti-mouse (Life Technologies; catalog \#A11005; RRID:AB_10561507) and Alexa Fluor 488conjugated anti-rabbit IgG (Life Technologies; catalog \#A11008; RRID: AB_10563748) for $2 \mathrm{~h}$ at RT. After a final washing with PBS, the slides or coverslips were mounted with the mounting medium (Prolong Gold Anti-fade Reagent; Invitrogen). Fluorescent images were acquired at RT on a Zeiss Observer using a Z1 inverted microscope with a $(40 \times$, numerical aperture 0.3 ) oil-immersion objective. Images were processed using the AxioVs 40 Version 4.8.0.0 software (Carl Zeiss). Photographs were acquired with an AxioCam MRm digital camera and were analyzed with NIH ImageJ software (ImageJ; RRID: nif-0000-30467).

Tissue and immunostaining. Formalin-fixed, paraffin-embedded sections $(5 \mu \mathrm{m})$ of frontal cortex from HIV-negative $\left(\mathrm{HIV}^{-}\right)$subjects and patients with HIV-E were obtained from the National NeuroAIDS Tissue Consortium (for clinical data, see Table 1) and stained with antibodies specific for rabbit NG2 antibodies (Millipore; catalog \#ab5320; RRID: AB_11213678; 1:200), mouse CD31 antibodies (Abcam; catalog \#ab24590; RRID: AB_448167; 1:100), mouse PDGF-BB antibodies (Abcam; catalog \#ab51869; RRID: AB_2299427; 1:100), and rabbit PDGFR- $\beta$ antibodies (Abcam; catalog \#ab32570; RRID: AB_777165; $1: 100)$ overnight at $4^{\circ} \mathrm{C}$. Sections were washed three times in PBS followed by incubation in Alexa Fluor 594-conjugated anti-mouse (Life Technologies; catalog \#A11005; RRID:AB_10561507) and Alexa Fluor 488-conjugated anti-rabbit IgG (Life Technologies; catalog \#A11008; RRID:AB_10563748) for $2 \mathrm{~h}$ at RT. After a final washing with PBS, sections were mounted with the mounting medium (Prolong Gold Antifade Reagent; Invitrogen). Fluorescent images were acquired at RT on a Zeiss Observer using a Z1 inverted microscope with a $(40 \times$, numerical aperture 0.3 ) oil-immersion objective. Images were processed using the AxioVs40 Version 4.8.0.0 software (Carl Zeiss). Photographs were acquired with an AxioCam MRm digital camera and were analyzed with NIH ImageJ software (ImageJ; RRID: nif-0000-30467).

Statistical analysis. Statistical analysis was performed using one-way ANOVA with a post hoc Student's $t$ test. Results were judged statistically significant if $p<0.05$ by ANOVA. 
A

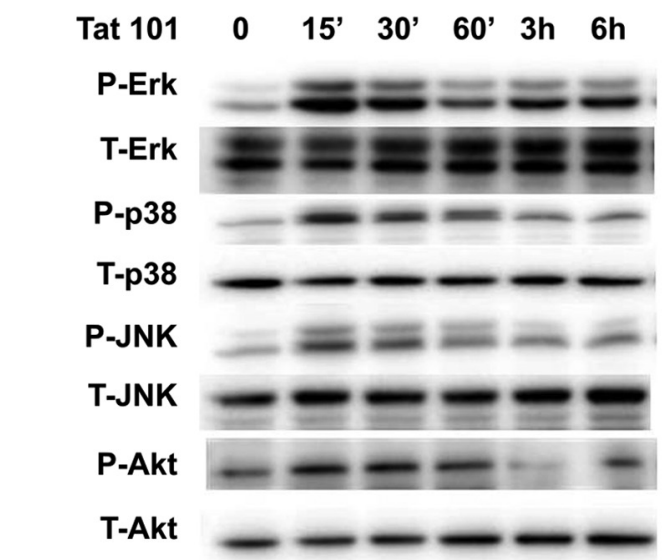

C

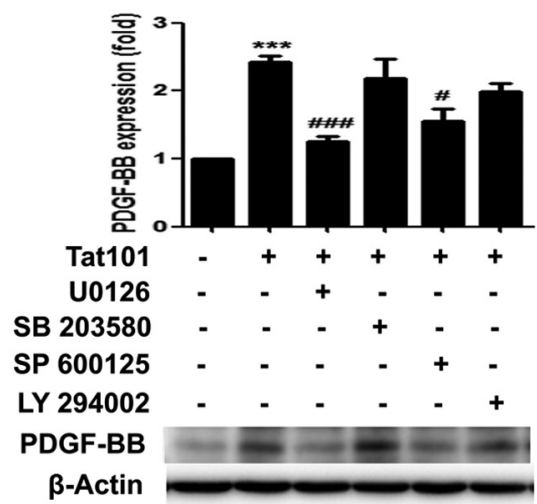

B
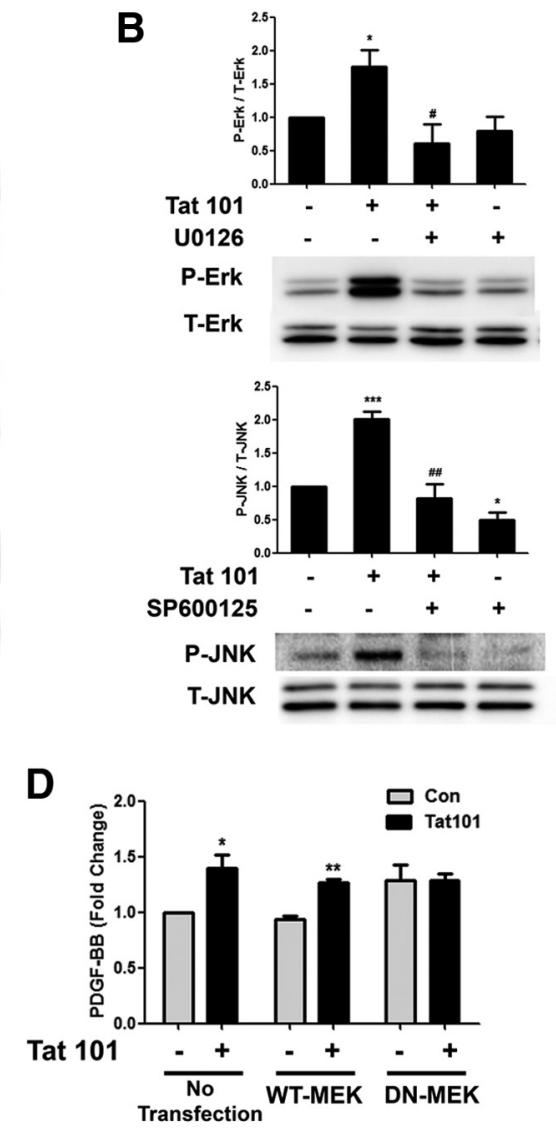

PDGF-BB

B-Actin
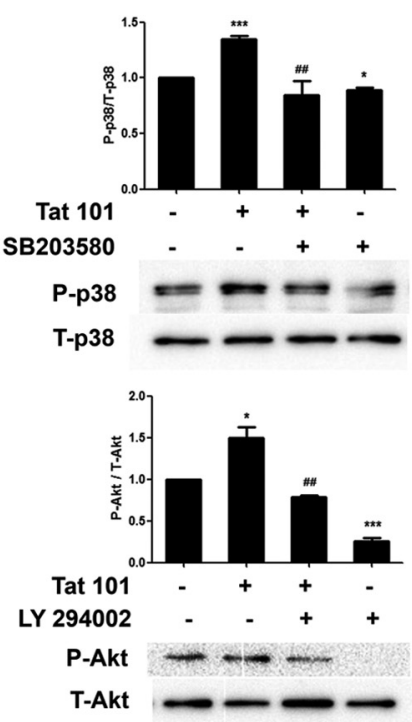

Figure 3. Tat101-mediated upregulation of PDGF-BB and pericyte migration involves activation of the ERK and JNK pathways. $A$, Tat101-mediated time-dependent activation of the ERK, p38, JNK, and PI3K/AKT pathways in C3H/10T1/2 cells. B, Pretreatment of C3H/10T1/2 cells with MEK (U0126), p38 (SB203580), JNK (SP600125), or PI3K (LY294002) inhibitors ameliorated Tat101mediated activation of the respective signaling pathways. C, Pharmacologic inhibition of the ERK and JNK pathways by MEK (U0126) and JNK (SP600125) inhibitors resulted in amelioration of Tat101-mediated induction of PDGF-BB expression. D, Transfection with DN-MEK but not WT-MEK constructs resulted in abrogation of Tat101-mediated induction of PDGF-BB. E, Transfection with DN-MEK but not WT-MEK resulted in abrogation of Tat101-mediated induction of migration. All data are presented as mean \pm SD of four individual experiments. ${ }^{*} p<0.05,{ }^{* *} p<0.01,{ }^{* * *} p<$ 0.001 versus the Con group. ${ }^{\#} p<0.05,{ }^{\#} p<0.01,{ }^{\# \# \#} p<0.001$ versus the Tat 101 -treated group (Student's $t$ test). T, Total.

\section{Results}

Tat101-mediated upregulation of PDGF-BB in C3H/10T1/2 cells and HBVPs

Because HIV Tat is known to induce expression of PDGF-BB in astrocytes (Bethel-Brown et al., 2011; Bethel-Brown et al., 2012) and endothelial cells (Mermis et al., 2011), we sought to examine whether pericytes also responded to HIV Tat by upregulating the expression of PDGF-BB. For this, the pericyte-like cell line $(\mathrm{C} 3 \mathrm{H} /$ 10T1/2) was exposed to HIV Tat101 (200 ng/ml) for varying times $(1,3,6,12$, and $24 \mathrm{~h})$, and an initial screen was done to identify the RNA levels of different PDGF chains that were expressed by real-time PCR. As shown in Figure 1A, PDGF-B mRNA was maximally upregulated (2.3-fold, $p=0.000629)$ at 3 h compared with other PDGF subtypes. For the sake of clarity, PDGF-A to PDGF-D refer to the RNA expression, whereas PDGF-AA to PDGF-DD refer to the protein expression of these genes. Based on these findings, all additional studies were focused on the PDGF-B chain. To confirm whether increased mRNA levels of PDGF-B translated into increased protein, Western blot analysis was done to determine the dose and time course of Tat101-mediated induction of PDGF-BB. For the dose curve,
C3H/10T1/2 cells were treated with either Tat101 for varying concentrations $(50,100$, and $200 \mathrm{ng} / \mathrm{ml})$ or heated Tat $(200 \mathrm{ng} /$ $\mathrm{ml}$ ), followed by protein extraction and assessment of PDGF-BB expression by Western blot. As shown in Figure 1B, Tat101 upregulated PDGF-BB expression in $\mathrm{C} 3 \mathrm{H} / 10 \mathrm{~T} 1 / 2$ cells in a concentration-dependent manner with maximal response at 200 $\mathrm{ng} / \mathrm{ml}$ (2.4-fold, $p=0.00353)$. Therefore, this concentration of Tat was used for all the experiments, and it must be noted that this is also a physiologically relevant concentration because the level of Tat protein in the CSF is $\sim 16 \mathrm{ng} / \mathrm{ml}$ (Westendorp et al., 1995 ), whereas that in the serum of HIV-positive patients is $\sim 40$ $\mathrm{ng} / \mathrm{ml}$, with actual concentration at tissue sites being even higher (Westendorp et al., 1995; Xiao et al., 2000; Toborek et al., 2005; Rumbaugh et al., 2006; Eugenin et al., 2007). As expected, heated Tat had no effect in inducing PDGF-BB. It should be noted that, with all the concentrations tested, Tat failed to exert any toxicity on pericytes as determined by cell viability assay (data not shown).

For the time course study, C3H/10T1/2 cells and HBVP cells were exposed to Tat101 $(200 \mathrm{ng} / \mathrm{ml})$ for varying time points ( $15 \mathrm{~min}$ to $24 \mathrm{~h}$ ), and as shown in Figure $1 C$, the ex- 
A

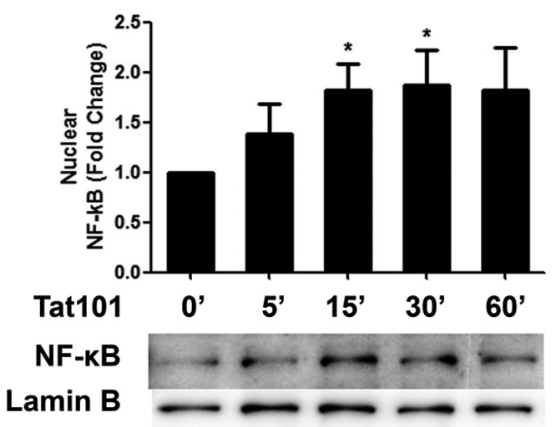

B

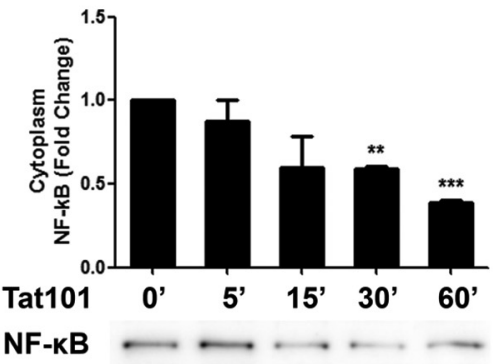

C

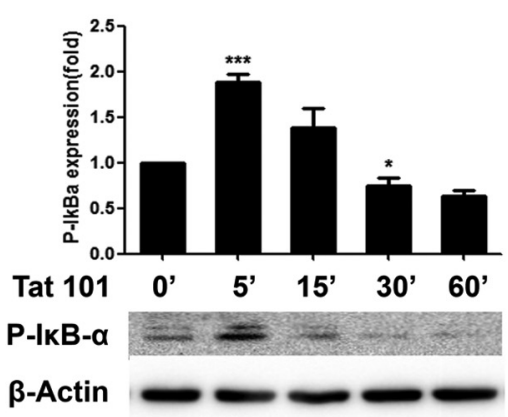

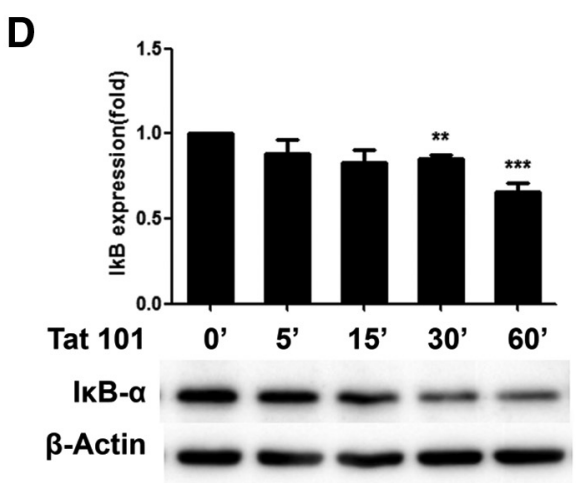

$\mathbf{F}$

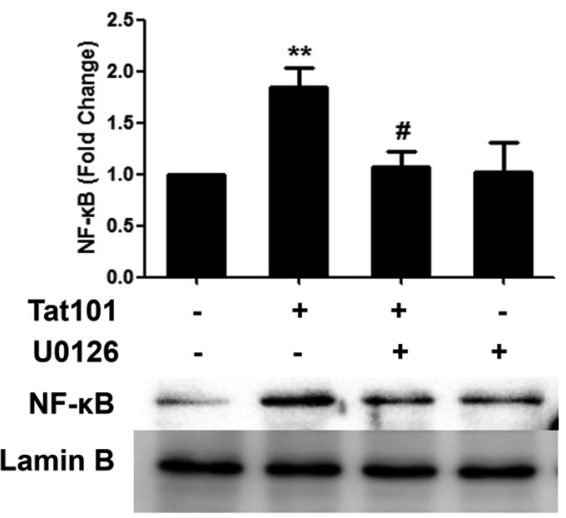

E

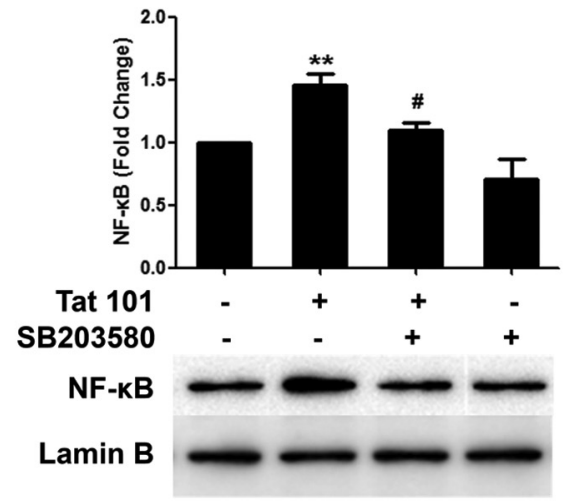

G

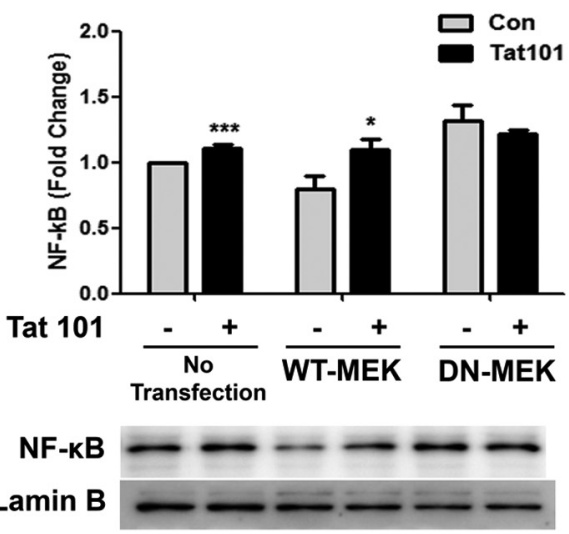

Figure 4. Tat101-mediated NF- $\kappa$ B activation in C $3 \mathrm{H} / 10 \mathrm{~T} 1 / 2$ cells. Nuclear and cytoplasm cell lysates from C3H/10T1/2 cells were isolated from treated cells and subjected to Western blot analysis using antibodies specific for NF- $\kappa$ B. Tat101 time dependently increased NF- $\kappa$ B protein expression in nuclear fraction $(\boldsymbol{A})$, with a concomitant decrease in cytoplasm $(\boldsymbol{B})$. $\boldsymbol{C}$, Tat101-mediated phosphorylation of $\mid \kappa B-\alpha$ in the cytoplasmic fraction of $(3 H / 10 T 1 / 2$ cells. D, Tat101-mediated degradation of $\mid \kappa B-\alpha$ in the cytoplasmic fraction $(3 H / 10 T 1 / 2$ cells. Pharmacologic inhibition of the JNK pathway by JNK inhibitor (SP600125) (E) and that of the ERK pathway by MEK inhibitor (U0126) (F) resulted in amelioration of Tat101-induced nuclear translocation of NF- $\kappa$ B. $\mathbf{G}$, Transfection with DN-MEK but not WT-MEK resulted in abrogation of Tat101-mediated activation of NF- $\kappa$ B. All data are presented as mean \pm SD of three individual experiments. ${ }^{*} p<0.05,{ }^{* *} p<0.01,{ }^{* * *} p<$ 0.001 versus the Con group. ${ }^{\#} p<0.05$ versus the Tat101-treated group (Student's $t$ test).

pression of PDGF-BB was induced by Tat101 as early as $1 \mathrm{~h}$ and continued to rise up to $\sim 24 \mathrm{~h}$ in both the cell types. Confirmation of these findings by immunostaining also revealed increased PDGF-BB expression in $\mathrm{C} 3 \mathrm{H} / 10 \mathrm{~T} 1 / 2$ cells and HBVPs at $24 \mathrm{~h}$ after Tat $101(200 \mathrm{ng} / \mathrm{ml})$ treatment. Images were captured by fluorescence microscopy using a $40 \times$ objective lens and analyzed by NIH Image software. As shown in Figure 1, $D$ and $E$, the intensity of PDGF-BB fluorescence was dramatically induced by Tat101, 6.2 -fold $(p=0.000196)$ for $\mathrm{C} 3 \mathrm{H} / 10 \mathrm{~T} 1 / 2$ cells and 4.1 -fold $(p=0.0113)$ for HBVPs. Together, these findings suggested that Tat101 mediated the induction of PDGF-B chain RNA and PDGF-BB protein in both C3H/10T1/2 cells and HBVPs.
Tat101 induces pericyte migration

To determine the functional effects of Tat-induced PDGF-BB, we sought to investigate whether Tat101 affected the migration of C3H/10T1/2 and HBVPs using two different assays. First, we monitored the migration of pericytes to varying concentrations of Tat $(50,100$, and $200 \mathrm{ng} / \mathrm{ml})$ or heated Tat $(200 \mathrm{ng} / \mathrm{ml})$ using the wound-healing assay. As shown in Figure 2, $A$ and $B$, there was a concentration-dependent effect on migration of $\mathrm{C} 3 \mathrm{H} /$ 10T1/2 and HBVPs in response to Tat101, with heated Tat exerting no effect on migration. In C3H/10T1/2 cells, concentrations of 100 and $200 \mathrm{ng} / \mathrm{ml}$ Tat101 promoted significant migration with maximal response observed at a concentration of $200 \mathrm{ng} / \mathrm{ml}$ $(\sim 1.3$-fold, $p=0.0282)$. In primary HBVPs, there was a 
concentration-dependent effect of Tat on migration that was significant at all the concentrations tested. Concentrations of 100 and $200 \mathrm{ng} / \mathrm{ml}$ Tat demonstrated a 2.0 -fold $(p=0.000185)$ and 1.8 -fold ( $p=$ $0.0001034)$ increase in migration, respectively, in HBVPs. Migration of $\mathrm{C} 3 \mathrm{H} /$ $10 \mathrm{~T} 1 / 2$ in response to HIV Tat was also validated using the Boyden chambers. Briefly, cells cultured in serum-free medium were seeded on the upper side of the transwell after exposure to varying concentrations of Tat101 (50-200 ng/ml or heated Tat) on both sides of the transwell. As shown in Figure 2C, $200 \mathrm{ng} / \mathrm{ml}$ Tat 101 significantly increased the migration of $\mathrm{C} 3 \mathrm{H} / 10 \mathrm{~T} 1 / 2$ cells $(\sim 1.3$-fold, $p=$ 0.0496), and, as expected, heated Tat 101 failed to promote migration. Thus, these findings demonstrated that exposure of $\mathrm{C} 3 \mathrm{H} / 10 \mathrm{~T} 1 / 2$ cells and HBVPs to Tat101 resulted in increased migration of these cells.

Tat101-mediated upregulation of PDGF-BB and pericyte migration involves activation of the ERK and JNK pathway Having determined that Tat101-mediated induction of PDGF-BB expression and pericyte migration, the next step was to elucidate the signaling pathways involved in this process. Because Tat signaling involves MAP kinases (MAPKs) and PI3K/Akt pathways, we examined the involvement of these pathways in Tat-mediated responses. Exposure of $\mathrm{C} 3 \mathrm{H} / 10 \mathrm{~T} 1 / 2$ cells to Tat 101 resulted in a time-dependent increase in phosphorylation of ERK1/2, p38, JNK, and Akt, with activation as early as 15 min after treatment (Fig. 3A). Specificity of these signaling pathways was subsequently assessed using a pharmacological approach. Pretreatment of cells with MEK (U0126, $2 \mu \mathrm{M})$, p38 (SB203580, $10 \mu \mathrm{M}$ ), JNK (SP600125, $2 \mu \mathrm{M}$ ), or PI3K (LY294002, $10 \mu \mathrm{M}$ ) inhibitors resulted in abrogation of Tat101-induced phosphorylation of ERK1/2, p38, JNK, and Akt (Fig. 3B), respectively.

We next sought to examine the functional role of MAPKs and PI3K/Akt in PDGF-BB expression and pericyte migration induced by Tat101. C3H/10T1/2 cells were pretreated with inhibitors specific for the respective signaling pathways for $1 \mathrm{~h}$, followed by exposure of $\mathrm{C} 3 \mathrm{H} / 10 \mathrm{~T} 1 / 2$ cells to Tat 101 for $24 \mathrm{~h}$ with assessment of PDGF-BB expression. As shown in Figure 3C, pretreatment of cells with MEK (U0126) and JNK (SP600126), but not p38 (SB203580) or PI3K (LY294002), inhibitors resulted in amelioration of Tat101-mediated induction of PDGF-BB expression. Additional validation of the involvement of the ERK pathway in Tat-mediated induction of PDGF-BB was performed using the DN constructs of MEK. For the transfection experiments, we included two controls: (1) a no-transfection control; and (2) a WT control. C3H/10T1/2 cells transfected with either the WT or DN construct of MEK were exposed to Tat 101 for $24 \mathrm{~h}$, followed by assessment of PDGF-BB expression in cell lysates. As shown in Figure 3D, Tat101-mediated induction of PDGF-BB was attenuated by DN-MEK but not by WT-MEK. These findings confirmed the involvement of MEK MAPKs but not p38 and PI3K/Akt cascade in Tat101-mediated induction of PDGF-BB in pericytes.

A similar experimental strategy described above was followed to validate the involvement of the ERK pathway in Tat101mediated migration of pericytes. Our findings demonstrated that Tat101-mediated induction of pericyte migration was amelio-
B

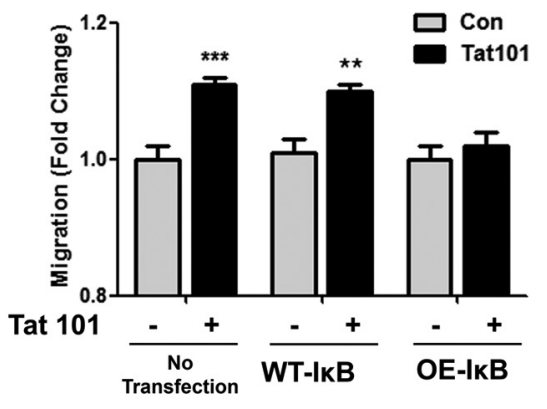

\section{Tat101-induced translocation of NF- $\kappa \mathrm{B}$ in pericytes}

The transcription factor NF- $\kappa \mathrm{B}$ has been shown to bind to elements upstream of the PDGF-B promoter (Chung et al., 2009). Because PDGF-BB was upregulated in pericytes after exposure to Tat, we next rationalized that this process involved activation of $\mathrm{NF}-\kappa \mathrm{B}$. Thus, we sought to examine translocation of NF- $\kappa \mathrm{B}$ p65 into the nucleus in pericytes exposed to Tat. C3H/10T1/2 cells were exposed to Tat for varying time points and assessed for translocation of the p65 subunit of NF- $\kappa \mathrm{B}$ in the nuclear fractions. As shown in Figure 4, $A$ and $B$, exposure of C3H/10T1/2 cells to Tat resulted in a time-dependent increase in translocation of the NF- $\kappa \mathrm{B}$ p 65 subunit in the nucleus with a concomitant decrease in the cytoplasm. A crucial step in the activation of $\mathrm{NF}-\kappa \mathrm{B}$ is the phosphorylation of $\mathrm{I} \kappa \mathrm{B}$ by the $\mathrm{I} \kappa \mathrm{B}$ kinase complex and subsequently degradation of $\mathrm{I} \kappa \mathrm{B}$. Additional elucidation of the NF- $\kappa \mathrm{B}$ activation pathway involved assessing expression of p-I $\kappa \mathrm{B}-\alpha$ and $\mathrm{I} \kappa \mathrm{B}-\alpha$ in the cytoplasm by Western blot. Our findings demonstrated rapid phosphorylation of $\mathrm{I} \kappa \mathrm{B}-\alpha$ with a concomitant decrease in total $\mathrm{I} \kappa \mathrm{B}-\alpha$ in the cytoplasm (Fig. $4 C, D$ ). Thus, these findings implied that Tat mediated activation of $\mathrm{NF}-\kappa \mathrm{B}$ in $\mathrm{C} 3 \mathrm{H} / 10 \mathrm{~T} 1 / 2$ cells.

The next logical step was to examine whether there was a link that could tie together the activation of ERK1/2 and JNK with NF- $\kappa$ B. C3H/10T1/2 cells were pretreated with MEK (U0126, 2 $\mu \mathrm{M})$ and JNK (SP600126) inhibitors, followed by exposure to Tat. As shown in Figure 4, $E$ and $F$, pretreatment of cells to MEK (U0126) and JNK (SP600126) inhibitors ameliorated Tat101mediated translocation of NF- $\kappa \mathrm{B}$. These findings suggested that upstream activation of the ERK1/2 pathway played a key role in downstream translocation of NF- $\kappa \mathrm{B}$ in Tat-exposed pericytes.

Additional validation of the involvement of the ERK1/2 pathway in this process was confirmed using a genetic approach. Briefly, C3H/10T1/2 cells were transfected with either the DN or WT construct of MEK, followed by exposure of transfected cells to Tat101 for $15 \mathrm{~min}$ and assessment of NF- $\kappa \mathrm{B}$ expression. As shown in Figure $4 G$ and as expected, Tat mediated an increase in translocation of NF- $\kappa \mathrm{B}$ in cells transfected with the WT construct. In contrast, Tat101-mediated translocation of NF- $\kappa$ B was 
A
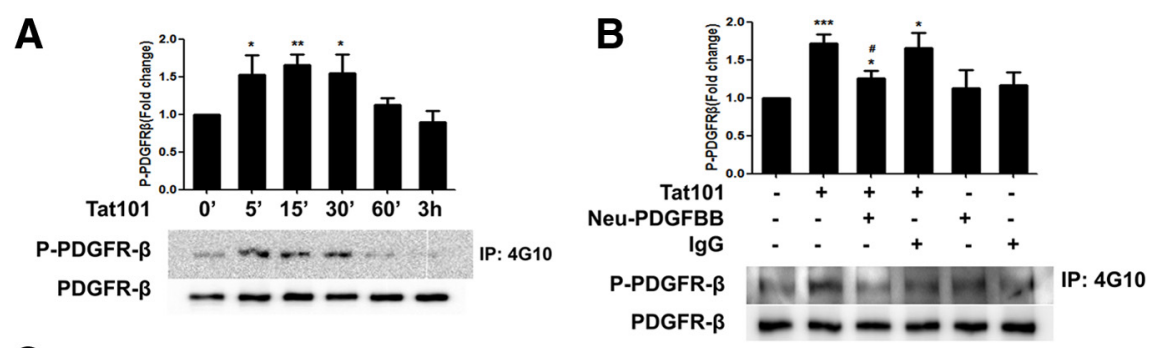

C
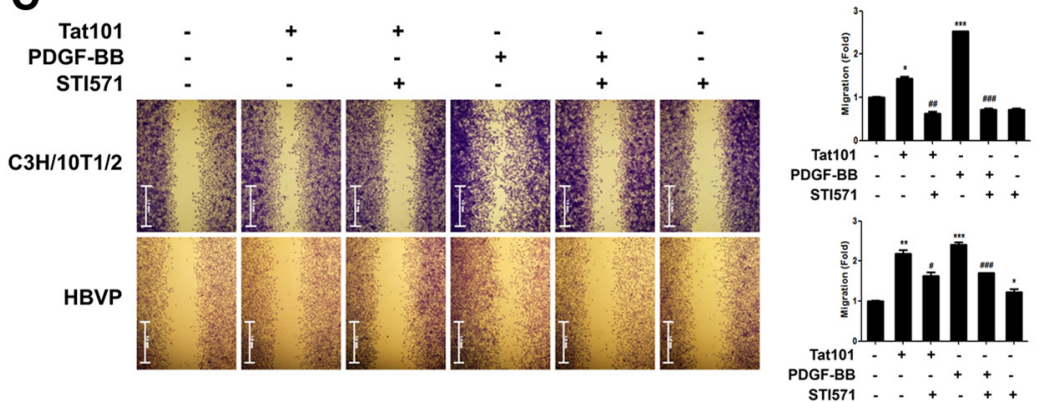

D

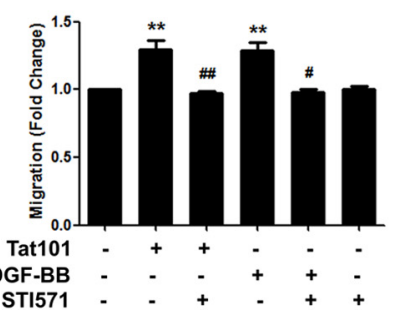

E

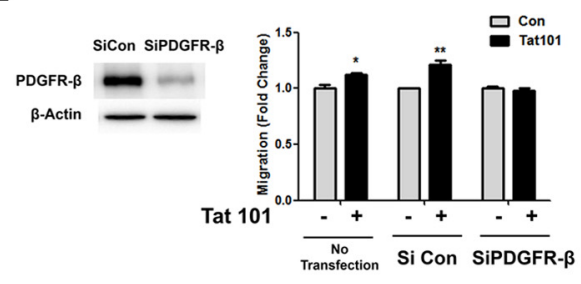

Figure 6. Involvement of PDGFR- $\beta$ in Tat101-induced migration of both $\mathrm{C} 3 \mathrm{H} / 10 \mathrm{~T} 1 / 2$ cells and HBVPs. $A$, Phosphorylation of PDGFR- $\beta$ induced by Tat101 $(200 \mathrm{ng} / \mathrm{ml})$ in C3H/10T1/2 cells. B, Pretreatment of cells with neutralizing PDGF-BB antibody partially ameliorated Tat101-mediated phosphorylation of PDGFR- $\beta$ induced by Tat101 $(200 \mathrm{ng} / \mathrm{ml})$ in C3H/10T1/2 cells. C, Pretreatment of C3H/10T1/2 cells and HBVPs with the PDGFR- $\beta$ inhibitor STI571 (10 $\mu \mathrm{M})$ ameliorated the migration induced by Tat101 $(200 \mathrm{ng} / \mathrm{ml})$ and PDGF-BB $(10 \mathrm{ng} / \mathrm{ml})$. PDGF-BB was used as a positive control. Migration was measured by the woundhealing assay and then analyzed by Tscratch software. Scale bars, $1.0 \mathrm{~mm}$. D, Tat 101-mediated increase in migration of $\mathrm{C} 3 \mathrm{H} /$ 10T1/2 cells measured by Boyden chamber migration assay was ameliorated in cells pretreated with STI571 (10 $\mu \mathrm{M})$. E, Western blot demonstrating silencing of PDGFR- $\beta$ in $\mathrm{C} 3 \mathrm{H} / 10 \mathrm{~T} 1 / 2$ cells transfected with PDGFR- $\beta$ siRNA (siPDGFR- $\beta$ ). Twenty four hours after transfection, cells were assessed for migration using the Boyden chamber migration assay. Tat101-mediated migration of pericytes was attenuated in cells transfected with PDGFR- $\beta$ siRNA but not in the nonsense siRNA transfected controls (siCon). All data are presented as mean $\pm S D$ of three individual experiments. ${ }^{*} p<0.05,{ }^{* *} p<0.01,{ }^{* * *} p<0.001$ versus the Con group. ${ }^{\#} p<0.05,{ }^{\# \#} p<0.01,{ }^{\# \# \#} p<0.001$ versus the Tat101- or PDGF-BB-treated group (Student's $t$ test).

attenuated in cells transfected with DN-MEK. Thus, these findings underpin the involvement of the ERK1/2 cascade in Tat101mediated activation of NF- $\kappa \mathrm{B}$ in $\mathrm{C} 3 \mathrm{H} / 10 \mathrm{~T} 1 / 2$ cells.

\section{Tat101-mediated induction of PDGF-BB and migration of pericytes involved NF- $\kappa \mathrm{B}$}

To elucidate the role of NF- $\kappa \mathrm{B}$ in Tat101-mediated induction of PDGF-BB, C3H/10T1/2 cells were transfected with either the WT or OE construct of $\mathrm{I} \kappa \mathrm{B}$, followed by exposure of cells to Tat 101 for $24 \mathrm{~h}$ and assessed for expression of PDGF-BB. As shown in Figure $5 A$, Tat101-mediated induction of PDGF-BB was attenuated in cells transfected with the $\mathrm{OE}-\mathrm{I} \kappa \mathrm{B}$ construct but not in cells transfected with the WT-I $\kappa$ B construct. Similar experiments were conducted to validate the involvement of NF- $\kappa \mathrm{B}$ in Tat101mediated migration of pericytes. Our findings demonstrated that Tat101-mediated induction of pericyte migration was ameliorated in cells transfected with OE-I $\kappa$ B but not in cells transfected with WT-I $\kappa \mathrm{B}$ (Fig. 5B). Thus, these findings underpin the role of NF- $\kappa B$ translocation in Tat101-mediated upregulation of PDGF-BB expression and pericyte migration.
Tat101-mediated induction of PDGFBB expression and pericyte migration involved activation of PDGFR- $\beta$

Based on the premise that Tat 101 induced both the expression of PDGF-BB and migration of pericytes and that activation of the ERK, JNK, and NF- $\kappa \mathrm{B}$ pathways played a role in these processes, the next step was to elucidate whether upregulated PDGF-BB exerted its effects via engagement of PDGFR- $\beta$ signaling in inducing Tat-mediated effects. We sought to examine first whether Tat could time dependently phosphorylate PDGFR- $\beta$. C3H/ 10T1/2 cells were treated with Tat101 for varying times ( $5 \mathrm{~min}$ to $3 \mathrm{~h}$ ), followed by assessment of the cell lysates for phosphorylation of PDGFR- $\beta$ by immunoprecipitation assay with the antiphosphotyrosine antibody (clone 4G10). As shown in Figure 6A, after Tat exposure, PDGFR- $\beta$ was phosphorylated as early as 5 min in C3H/10T1/2 cells. To confirm whether PDGF-BB released after Tat exposure was critical for activation of PDGFR- $\beta$, cells were pretreated with either the neutralizing anti-PDGF-BB or the normal IgG antibody, followed by treatment with Tat101 for 30 min and assessed for phosphorylation of PDGFR- $\beta$. As shown in Figure $6 B$, cells pretreated with the neutralizing PDGF-BB antibody failed to exhibit phosphorylation of PDGFR- $\beta$ after exposure to Tat. However, as expected, control antibodytreated cells demonstrated Tat-mediated phosphorylation of the PDGFR- $\beta$. These results implicate that Tat101-mediated release of PDGF-BB was critical for activation of the PDGFR- $\beta$.

We next sought to elucidate whether PDGFR- $\beta$ activation played a role in Tat101-mediated migration of pericytes. To answer this, both $\mathrm{C} 3 \mathrm{H} / 10 \mathrm{~T} 1 / 2$ cells and HBVPs were pretreated with the tyrosine kinase inhibitor STI571 to block PDGFR- $\beta$ signaling and then assessed for Tat101-mediated migration of pericytes using the wound-healing and the Boyden chamber migration assay. Migration with PDGF-BB (10 ng/ml) was used as a positive control. As shown in Figure 6, $C$ and $D$, pretreatment of cells with STI571 resulted in significant amelioration of Tat101-mediated migration of pericytes.

Additional validation of the involvement of PDGFR- $\beta$ in Tat101-mediated migration of pericytes was performed in cells transfected with the siRNA for PDGFR- $\beta$. Briefly, C3H/10T1/2 cells were transfected with either the PDGFR- $\beta$ or the nonsense (control) siRNA for $24 \mathrm{~h}$, followed by exposure of cells to Tat 101 and assessment of cell migration using the Boyden chamber assay. As shown in Figure $6 E$, transfection of $\mathrm{C} 3 \mathrm{H} / 10 \mathrm{~T} 1 / 2$ cells with PDGFR- $\beta$ siRNA resulted in efficient knockdown of PDGFR- $\beta$ as demonstrated by Western blot. Furthermore, Tat101-mediated migration of pericytes was attenuated in cells transfected with PDGFR- $\beta$ siRNA but not in the nonsense siRNA transfected con- 
A

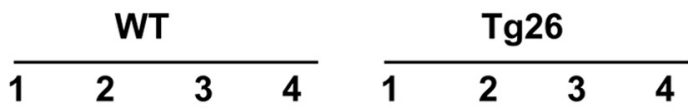

Tat

$\beta$-Actin

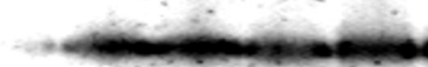

$22 \mathrm{kDa}$

$42 \mathrm{kDa}$

\section{WT}

B

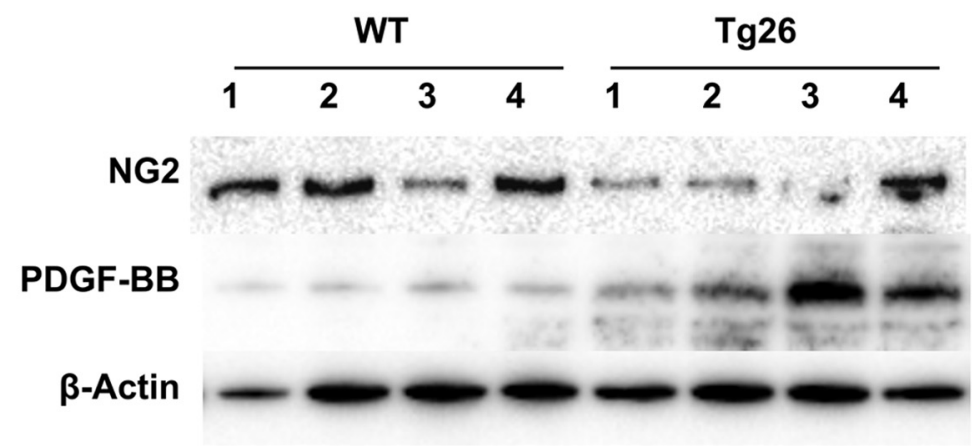

270kDa

$27 \mathrm{kDa}$

$42 \mathrm{kDa}$

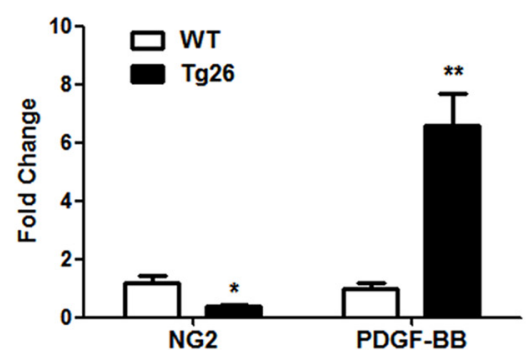

C NG2 CD31 DAPI Merge WT
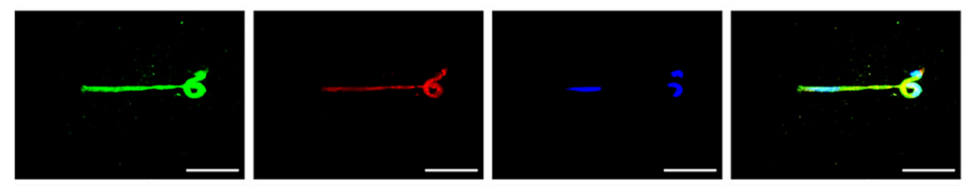

$\operatorname{Tg} 26$
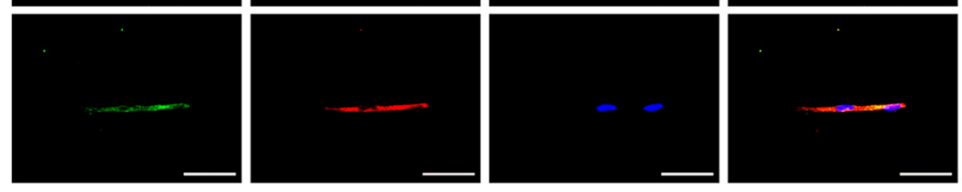

D
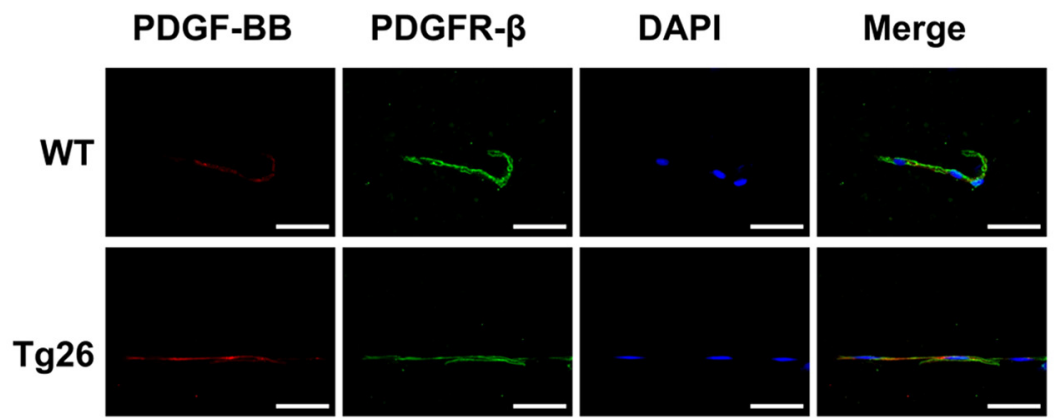
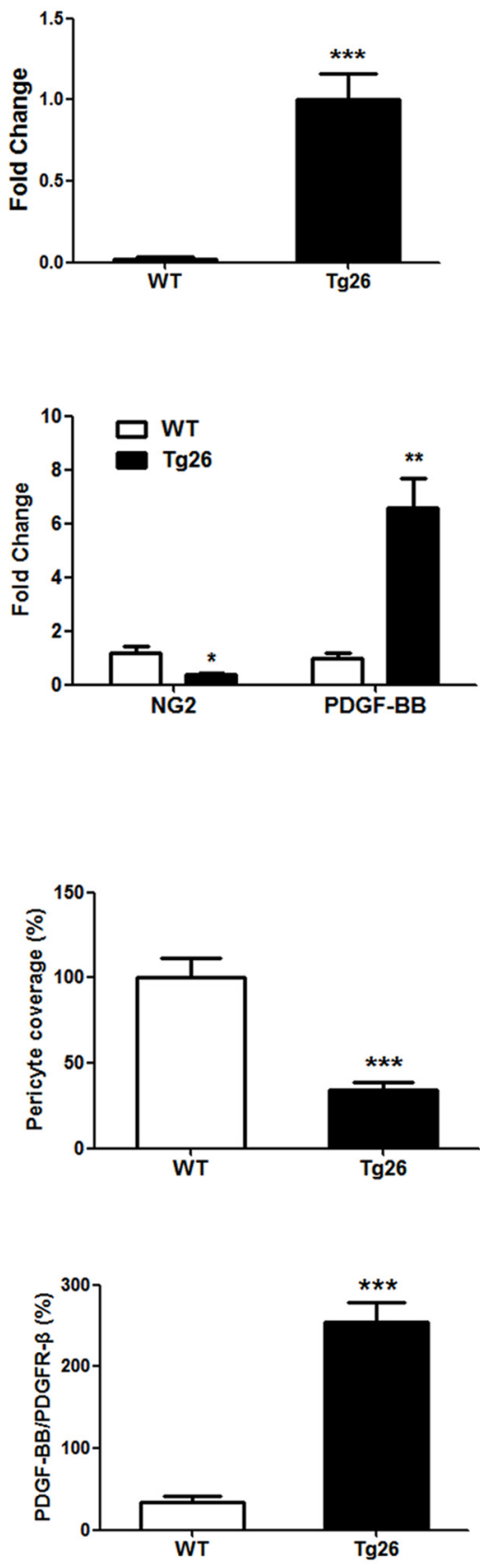

Figure 7. Increased pericyte loss in the brains of HIV Tg26 mice. $\boldsymbol{A}$, HIV Tat expression was detected in microvessels isolated from HIV- 1 Tg2 6 but not in the WT mice ( $n=4$ per group). $\boldsymbol{B}$, NG2 and PDGF-BB expression was detected in isolated microvessels of HIV- 1 Tg26 and WT mice by Western blot ( $n=4$ per group). C, Double immunostaining of the pericyte marker NG2 (green) and the endothelial cell marker CD31 (red) in isolated microvessels of HIV-1 Tg26 and WT mice. The analyzed data demonstrated that isolated microvessels in HIV-1 Tg26 mice exhibited reduced pericyte coverage compared with the microvessels isolated from WT mice. NG2, Green; CD31, red; nucleus, blue. $n=4$ per group. Scale bar, $20 \mu \mathrm{m}$. D, Double immunostaining of PDGF-BB (red) and PDGFR- $\beta$ (green) in isolated microvessels of HIV-1 Tg26 and WT mice. HIV-1 Tg26 mice exhibited higher expression of PDGF-BB than the microvessels isolated from the WT mice. PDGF-BB, Red; PDGFR- $\beta$, green; nucleus, blue; merge, yellow. $n=4$ per group. Scale bar, $20 \mu \mathrm{m} .{ }^{*} p<0.05,{ }^{* *} p<0.01,{ }^{* * *} p<0.001$ versus the Con group (Student's $t$ test).

trols. Together, these findings confirmed that Tat101-mediated release of PDGF-BB played a key role in engaging the PDGFR- $\beta$ signaling that was critical for migration of pericytes.

Increased pericyte loss in the brains of HIV Tg26 mice Having determined that Tat mediated induction of PDGF-BB in cultured pericytes, we next sought to assess the expression levels of PDGF in HIV Tg26 mice. However, before examining the levels of PDGF, it was important first to assess the expression of HIV Tat in these animals compared with the WT con- trols (either sex; $n=4$ ). As shown in Figure $7 A$ and as expected, homogenates from brain microvessels from HIV Tg26 mice expressed HIV Tat protein, whereas those from WT mice did not. Next we assessed the expression of PDGF-BB in the homogenates from isolated microvessels of WT and HIV Tg26 mice (6-8 months old) in conjunction with the assessment of the pericyte marker (NG2) using Western blot and immunofluorescence staining. As shown in Figure $7 \mathrm{~B}$, microvessels isolated from Tg26 mice demonstrated reduced expression of NG2 (0.42-fold, $p=0.0267)$, with a concomitantly 
A

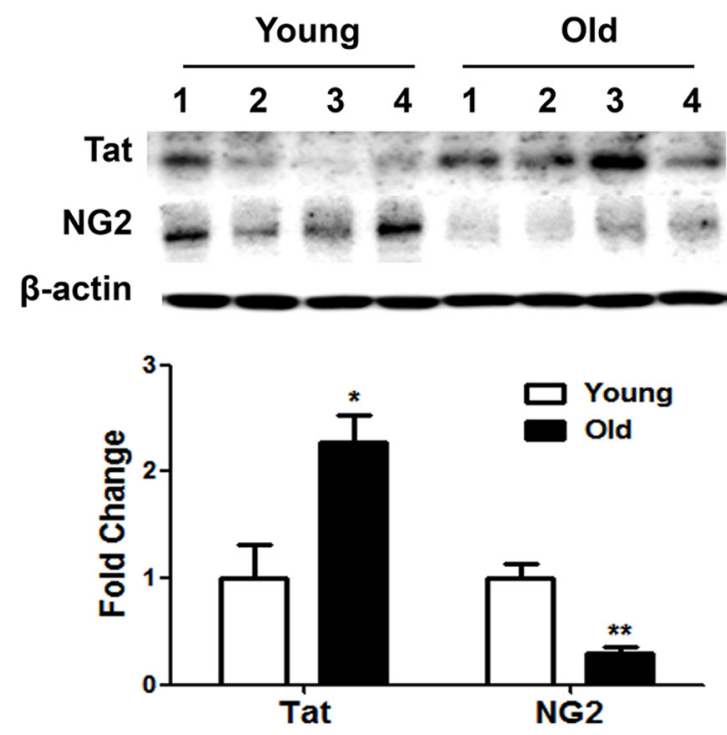

NG2

C

HIV-

HIV-E
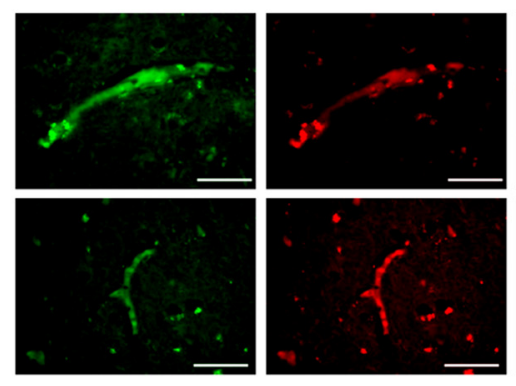

D

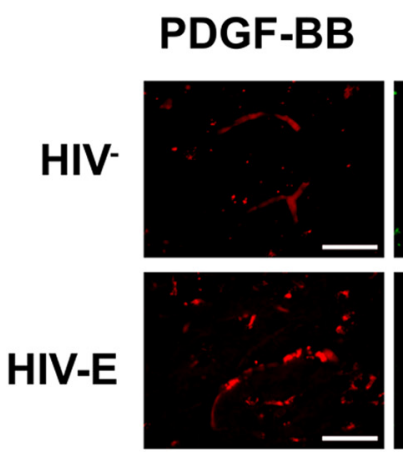

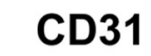
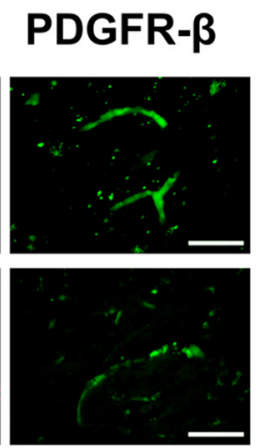

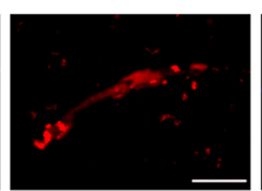

DAPI
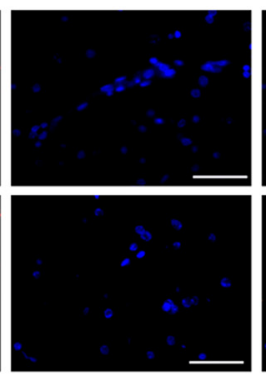

DAPI
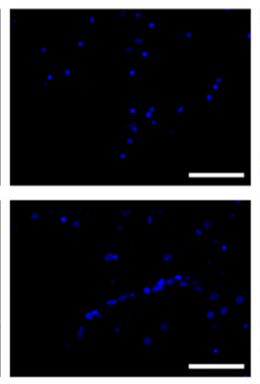

B

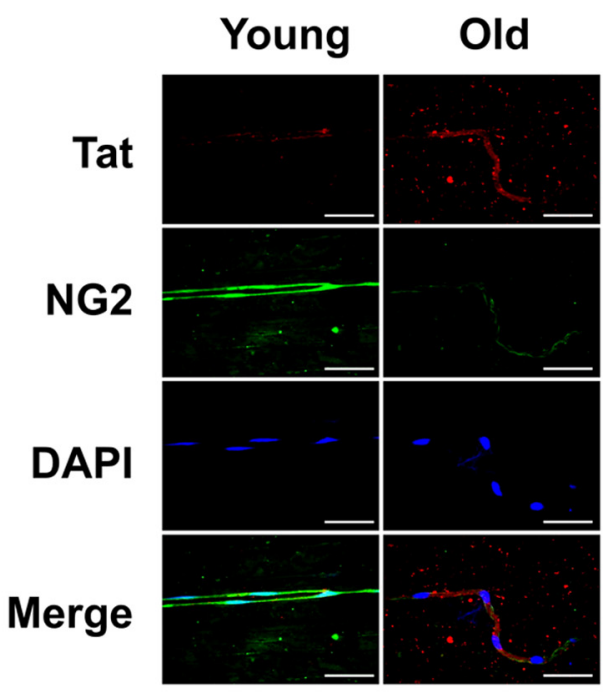

Figure 8. L Loss of pericytes in brains of HIV Tg26 mice and in humans with HIV-E. A, NG2 and HIV Tat expression was detected in microvessels isolated from young versus old HIV-1 Tg26 mice by Western blot ( $n=4$ per group). B, Double immunostaining of the pericyte marker NG2 (green) and HIV Tat (red) in isolated microvessels of young and old HIV-1 Tg26 mice. NG2, Green; Tat, red; nucleus, blue. $n=4$ per group. Scale bar, $20 \mu \mathrm{m}$. C, Double immunostaining of pericyte (NG2, green) and endothelial cell marker (CD31, red) in cortical sections of autopsied brains of HIV ${ }^{-}$and HIV-E individuals. NG2, Green; CD31, red; nucleus, blue. $n=3$ per group. Scale bar, $20 \mu \mathrm{m}$. D, Double immunostaining of PDGF-BB (red) and PDGFR- $\beta$ (green) in microvessels isolated from HIV-E sections compared with those from uninfected subjects. PDGF-BB, Red; PDGFR- $\beta$, green; nucleus, blue; merged, yellow. $n=3$ per group. Scale bar, $20 \mu \mathrm{m}$. ${ }^{*} p<0.05$, ${ }^{* *} p<0.01$ versus the Con group (Student's $t$ test).

increased expression of PDGF-BB (6.5-fold, $p=0.00274)$ compared with the microvessels isolated from the WT mice.

The next step was to assess by double immunostaining the pericyte coverage around the endothelium using antibodies specific for pericytes (NG2; green color) and for the endothelial cell marker (CD31; red color) on sections of microvessels isolated from $\operatorname{Tg} 26$ mice. As shown in Figure $7 C$, there was reduced expression ( 0.34 -fold, $p=0.000848$ ) of the pericyte marker NG2 in microvessels isolated from HIV-1 Tg26 mice, suggesting reduced pericyte coverage compared with the WT mice. Microvessels from HIV-1 Tg26 and WT mice were also subjected to double immunostaining using antibodies specific for PDGF-BB (red color) and PDGFR- $\beta$ (pericyte marker, green color). As shown in Figure $7 D$, there was increased expression of PDGF-BB (8.3-fold, $p=0.000227)$ in PDGFR- $\beta$-positive pericytes in the microvessels isolated from HIV-1 Tg26 compared with the WT mice. Intriguingly, levels of PDGFR- $\beta$ were reduced in microvessels isolated from HIV-1 Tg26 compared with the WT mice. 


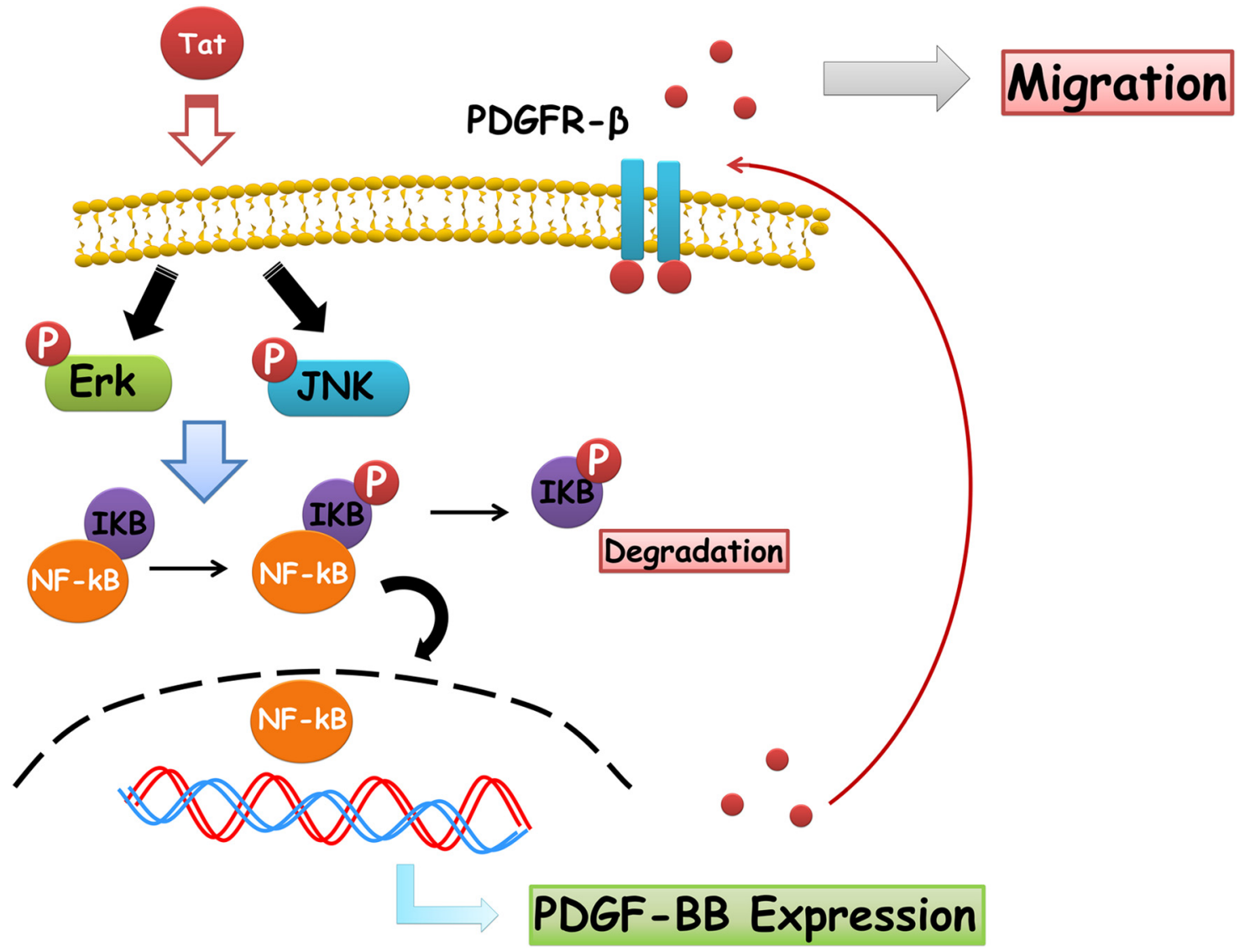

Figure 9. Schematic diagram demonstrating the signaling pathways involved in Tat101-mediated induction of PDGF-BB and pericyte migration. Tat stimulates the ERK and JNK MAPK pathways, which in turn leads to NF- $\kappa$ B translocation, with the subsequent induction of PDGF-BB. Elevated PDGF-BB via autocrine PDGFR- $\beta$ signaling ultimately leads to increased pericyte migration and loss in microvessels within the brain.

\section{Loss of pericytes in brains of HIV Tg26 mice and in humans with HIV-E}

To further unravel the relationship of increased Tat expression and pericyte loss, microvessels were isolated from young $(<2$ months) and old ( $>1$ year) HIV Tg26 mice and assessed for expression of Tat and NG2 by Western blot (either sex; $n=4$ ). As shown in Figure $8 A$ and as expected, microvessels isolated from older Tg26 mice demonstrated higher expression of HIV Tat (2.8-fold, $p=0.0183$ ) compared with the microvessels isolated from young $\operatorname{Tg} 26$ mice. This was accompanied by reduced expression of NG2 (0.30-fold, $p=0.00312)$ in the microvessels from older HIV Tg26 mice compared with the younger animals. These findings were further validated in sections of isolated microvessels from young and old Tg26 mice by double immunostaining using antibodies specific for pericytes (NG2; green color) and for HIV Tat (red color). As shown in Figure $8 B$, there was reduced expression of the pericyte marker NG2 in isolated microvessels from old Tg26 mice compared with the young Tg26 mice, and this was accompanied by a higher expression of Tat in the old Tg26 mice, as expected.

To further validate whether HIV Tat resulted in reduced pericyte coverage in the endothelium in the setting of HIV, sections of the frontal cortex obtained from autopsied brains of HIV-E and uninfected individuals $(n=3)$ were double immunostained for pericyte (NG2; green color), as well as endothelial cell marker (CD31; red color). As shown in Figure $8 C$, there was reduced expression of the pericyte marker NG2 in sections of brains from patients with HIV-E $(0.20$-fold, $p=0.00193)$ compared with the
$\mathrm{HIV}^{-}$control individuals, thereby suggesting reduced pericyte coverage in the microvessels of HIV-E patients. Brain sections from HIV-E and $\mathrm{HIV}^{-}$control individuals were also subjected to double immunostaining using antibodies specific for PDGF-BB (red color) and PDGFR- $\beta$ (pericyte marker, green color). As shown in Figure $8 D$, there was increased expression of PDGF-BB (2.5-fold, $p=0.0125$ ) in PDGFR- $\beta$-positive pericytes from HIV-E patients compared with uninfected controls.

\section{Discussion}

One of the underlying features leading to neuroinflammation associated with HANDs is the breach of the cerebrovascular unit. Various reports implicate disruption of this unit during HIV-1 infection (Masiá et al., 2010; McArthur et al., 2010), with a prominent role of the viral protein HIV-1 Tat in this process (Banks et al., 2005). Although the information on endothelium and astrocyte dysfunction in HANDs is extant (Toborek et al., 2003; Eugenin et al., 2011; Ramirez et al., 2013), relatively little is known about the role of the pericytes, the less studied but a very important cell type of the cerebrovascular unit in this process. Pericytes play a crucial role in maintaining the functions of microvessels, controlling the capillary diameter, and in preserving the integrity of the BBB. More recently, an additional role of pericytes has been identified: that of promoting HIV replication (Nakagawa et al., 2012). Furthermore, similar to glial cell activation by inflammatory agents, pericytes have also been shown to be activated in response to LPS, leading to release of mediators that aid in pro- 
moting transcytosis of HIV-1 virus across the BBB (Dohgu and Banks, 2013).

Among the viral products, HIV Tat has been shown to be neuroexcitatory and neurotoxic, and it continues to be a causative agent underlying pathogenesis of HANDs (Buscemi et al., 2007; Agrawal et al., 2012). Tat can be both secreted from infected cells and taken up by neighboring non-infected cells, including but not limited to neurons (Liu et al., 2000). Gene coding for HIV Tat consists of two spliced exons separated by $>2300 \mathrm{nt}$. The highly conserved protein of 101 residues is synthesized after complete splicing of the viral pre-mRNA. The rationale for using Tat101 in this study was based on the premise that Tat101 is most common protein in clinical HIV isolates (López-Huertas et al., 2010). Although pericytes are known to facilitate HIV replication, there is paucity of information on how Tat exerts its toxicity in these cells. Because Tat is present in the CNS despite antiretroviral therapy (ART) (Mediouni et al., 2012), we sought to examine whether Tat exposure could affect pericyte loss, thereby leading to BBB breach associated with HANDs.

PDGF plays a critical role in pericyte functioning under both physiological and pathological conditions (Lindahl et al., 1997; McCarty et al., 2007). For example, under physiological conditions, PDGF has been shown to be critical for pericyte recruitment, survival, and coverage of the endothelium (Lindahl et al., 1997; Nadal et al., 2002; Stratman et al., 2010). In contrast, under pathological conditions such as cancer, it has been shown that overexpression of PDGF-BB by tumor cells increases pericyte content of the tumor milieu, resulting in a protective phenotype via inhibition of tumor angiogenesis and growth (McCarty et al., 2007). Recent reports suggest that the PDGF content of the tumor milieu determines the fate of the pericytes (Hosaka et al., 2013). PDGF-BB, a potent chemotactic factor for targeted cells, has been shown to increase migration of retinal microvascular pericytes (Nadal et al., 2002). Based on this premise, we hypothesized that Tat-mediated increased migration of pericytes could, in part, be a mechanism resulting in loss of pericyte coverage in the HIV-1infected brain.

In the present study, we demonstrated that exposure of both pericyte cell line $\mathrm{C} 3 \mathrm{H} / 10 \mathrm{~T} 1 / 2$ cells and HBVPs to Tat 101 resulted in induction of the PDGF-B chain at both the transcriptional and translational levels. Tat-mediated increased expression of PDGF-BB is in agreement with previous studies (Mermis et al., 2011; Bethel-Brown et al., 2012), demonstrating that both HIV-1 infection and HIV proteins can induce the expression of PDGF-BB in other cells types, as well as endothelial cells and astrocytes. Additional dissection of the signaling pathways involved in Tat-mediated induction of PDGF-BB using pharmacological and genetic approaches revealed activation of ERK, JNK, p38 MAPKs, and PI3K/Akt pathways, a finding that is consistent with previous reports on the effects of Tat in astrocytes and neurons (Eugenin et al., 2007; Yao et al., 2009, 2010). However, Tatmediated induction of PDGF-BB expression involved ERK and JNK MAPKs but not the p38 MAPK or PI3K/Akt pathways.

The transcription factor NF- $\kappa \mathrm{B}$ has emerged as a major regulatory transcription factor for a number of genes, including growth factors such as PDGF-BB (Silverman and Collins, 1999; James et al., 2005). Our findings demonstrated a time-dependent translocation of NF- $\kappa \mathrm{B}$ in $\mathrm{C} 3 \mathrm{H} / 10 \mathrm{~T} 1 / 2$ cells. Additional dissection of NF- $\kappa$ B regulation using both the pharmacological and genetic approaches revealed that activation of the ERK and JNK MAPK pathways were upstream of NF- $\kappa$ B. In agreement with our previous findings (Bethel-Brown et al., 2011), upstream activation of the ERK and JNK pathways with subsequent translo- cation of NF- $\kappa$ B p65 was critical for Tat-mediated effects in pericytes.

Additional support of NF- $\kappa \mathrm{B}$ involvement in Tat-mediated induction of PDGF-BB was also demonstrated using both the siRNA and genetic approaches. Our findings are in agreement with the report by Khachigian et al. $(1995,1996)$ demonstrating interaction of NF- $\kappa \mathrm{B}$ with the PDGF-B promoter in arterial endothelial cells.

Our findings also suggested that Tat101 could phosphorylate PDGFR- $\beta$ directly and also through the released PDGF-BB via the autocrine mechanism, as demonstrated by blocking of the released PDGF-BB using the neutralizing antibody. Additional evaluation of the functional role of activated PDGFR- $\beta$ was confirmed by using migration assays. Pretreatment of the pericytes with either the receptor tyrosine kinase antagonist, such as STI571, or the PDGFR- $\beta$ siRNA was able to abrogate Tatmediated migration of the pericytes, thereby implicating the role of PDGF signaling in this process. Together, these findings suggest Tat-mediated autocrine activation of the PDGF/PDGFR- $\beta$ axis as a trigger for cell migration, which in turn could lead to reduced pericyte coverage with a concomitant BBB breach and associated neuroinflammation observed in HANDs.

Additional validation of these findings was also demonstrated ex vivo, wherein higher expression of PDGF-BB with a concomitant reduction in expression of NG2 pericytes in microvessels isolated from HIV-1 Tg26 mice. Similar to Tat Tg26 mice, reduced pericyte coverage was also observed in sections of frontal cortex from brains of individuals with HIV-E compared with uninfected controls.

To further unravel the effect of HIV Tat on pericyte loss, we resorted to examining the expression of the pericyte marker NG2 in the microvessels isolated from young ( $<2$ months) versus old $(>1$ year) HIV Tg26 mice, the rationale being that older mice would exhibit increased HIV Tat accumulation because of longer expression of the transgene compared with the younger animals. Indeed, we did observe that increased Tat expression correlated with increased pericyte loss. These findings lend credence to the role of Tat in mediating loss of pericyte coverage on the brain endothelium. Together, these findings could have implications for impaired functioning of the cerebrovascular unit in HANDs, leading to breach of the brain endothelium and ultimately to increased influx of inflammatory cells in the CNS.

In summary, our findings have demonstrated a detailed molecular pathway of Tat101-mediated expression of PDGF-BB and pericyte migration both in vitro and ex vivo. Tat-mediated induction of PDGF-BB expression in pericytes involves ERK and JNK MAPK activation, with the subsequent activation of NF- $\kappa \mathrm{B}$ (as summarized in Fig. 9). We further show elevated PDGF-BB activated autocrine PDGFR- $\beta$ signaling, ultimately leading to increased pericyte migration and loss in microvessels within the brain.

\section{References}

Agrawal L, Louboutin JP, Reyes BA, Van Bockstaele EJ, Strayer DS (2012) HIV-1 Tat neurotoxicity: a model of acute and chronic exposure, and neuroprotection by gene delivery of antioxidant enzymes. Neurobiol Dis 45:657-670. CrossRef Medline

Banks WA, Robinson SM, Nath A (2005) Permeability of the blood-brain barrier to HIV-1 Tat. Exp Neurol 193:218-227. CrossRef Medline

Bell RD, Winkler EA, Sagare AP, Singh I, LaRue B, Deane R, Zlokovic BV (2010) Pericytes control key neurovascular functions and neuronal phenotype in the adult brain and during brain aging. Neuron 68:409-427. CrossRef Medline

Bethel-Brown C, Yao H, Callen S, Lee YH, Dash PK, Kumar A, Buch S (2011) 
HIV-1 Tat-mediated induction of platelet-derived growth factor in astrocytes: role of early growth response gene 1. J Immunol 186:4119-4129. CrossRef Medline

Bethel-Brown C, Yao H, Hu G, Buch S (2012) Platelet-derived growth factor (PDGF)-BB-mediated induction of monocyte chemoattractant protein 1 in human astrocytes: implications for HIV-associated neuroinflammation. J Neuroinflammation 9:262. CrossRef Medline

Buscemi L, Ramonet D, Geiger JD (2007) Human immunodeficiency virus type-1 protein Tat induces tumor necrosis factor-alpha-mediated neurotoxicity. Neurobiol Dis 26:661-670. CrossRef Medline

Chung CH, Lin KT, Chang CH, Peng HC, Huang TF (2009) The integrin alpha2betal agonist, aggretin, promotes proliferation and migration of VSMC through NF- $\kappa$ B translocation and PDGF production. Br J Pharmacol 156:846-856. CrossRef Medline

Dickie P, Felser J, Eckhaus M, Bryant J, Silver J, Marinos N, Notkins AL (1991) HIV-associated nephropathy in transgenic mice expressing HIV-1 genes. Virology 185:109-119. CrossRef Medline

Dohgu S, Banks WA (2013) Brain pericytes increase the lipopolysaccharideenhanced transcytosis of HIV-1 free virus across the in vitro blood-brain barrier: evidence for cytokine-mediated pericyte-endothelial cell crosstalk. Fluids Barriers CNS 10:23. CrossRef Medline

Eugenin EA, King JE, Nath A, Calderon TM, Zukin RS, Bennett MV, Berman JW (2007) HIV-tat induces formation of an LRP-PSD-95- NMDARnNOS complex that promotes apoptosis in neurons and astrocytes. Proc Natl Acad Sci U S A 104:3438-3443. CrossRef Medline

Eugenin EA, Clements JE, Zink MC, Berman JW (2011) Human immunodeficiency virus infection of human astrocytes disrupts blood-brain barrier integrity by a gap junction-dependent mechanism. J Neurosci 31 : 9456-9465. CrossRef Medline

Gebäck T, Schulz MM, Koumoutsakos P, Detmar M (2009) TScratch: a novel and simple software tool for automated analysis of monolayer wound healing assays. Biotechniques 46:265-274. CrossRef Medline

Hosaka K, Yang Y, Seki T, Nakamura M, Andersson P, Rouhi P, Yang X, Jensen L, Lim S, Feng N, Xue Y, Li X, Larsson O, Ohhashi T, Cao Y (2013) Tumour PDGF-BB expression levels determine dual effects of anti-PDGF drugs on vascular remodelling and metastasis. Nat Commun 4:2129. CrossRef Medline

Hsue PY, Hunt PW, Wu Y, Schnell A, Ho JE, Hatano H, Xie Y, Martin JN, Ganz P, Deeks SG (2009) Association of abacavir and impaired endothelial function in treated and suppressed HIV-infected patients. AIDS 23:2021-2027. CrossRef Medline

James AB, Conway AM, Morris BJ (2005) Genomic profiling of the neuronal target genes of the plasticity-related transcription factor-Zif268. J Neurochem 95:796-810. CrossRef Medline

Khachigian LM, Resnick N, Gimbrone MA Jr, Collins T (1995) Nuclear factor-kappa B interacts functionally with the platelet-derived growth factor B-chain shear-stress response element in vascular endothelial cells exposed to fluid shear stress. J Clin Invest 96:1169-1175. CrossRef Medline

Khachigian LM, Lindner V, Williams AJ, Collins T (1996) Egr-1-induced endothelial gene expression: a common theme in vascular injury. Science 271:1427-1431. CrossRef Medline

Kim TA, Avraham HK, Koh YH, Jiang S, Park IW, Avraham S (2003) HIV-1 Tat-mediated apoptosis in human brain microvascular endothelial cells. J Immunol 170:2629-2637. CrossRef Medline

Kopp JB, Klotman ME, Adler SH, Bruggeman LA, Dickie P, Marinos NJ, Eckhaus M, Bryant JL, Notkins AL, Klotman PE (1992) Progressive glomerulosclerosis and enhanced renal accumulation of basement membrane components in mice transgenic for human immunodeficiency virus type 1 genes. Proc Natl Acad Sci U S A 89:1577-1581. CrossRef Medline

Lindahl P, Johansson BR, Levéen P, Betsholtz C (1997) Pericyte loss and microaneurysm formation in PDGF-B-deficient mice. Science 277:242245. CrossRef Medline

Liu Y, Jones M, Hingtgen CM, Bu G, Laribee N, Tanzi RE, Moir RD, Nath A, He JJ (2000) Uptake of HIV-1 tat protein mediated by low-density lipoprotein receptor-related protein disrupts the neuronal metabolic balance of the receptor ligands. Nat Med 6:1380-1387. CrossRef Medline

López-Huertas MR, Callejas S, Abia D, Mateos E, Dopazo A, Alcamí J, Coiras M (2010) Modifications in host cell cytoskeleton structure and function mediated by intracellular HIV-1 Tat protein are greatly dependent on the second coding exon. Nucleic Acids Res 38:3287-3307. CrossRef Medline

Masiá M, Padilla S, García N, Jarrin I, Bernal E, López N, Hernández I,
Gutiérrez F (2010) Endothelial function is impaired in HIV-infected patients with lipodystrophy. Antivir Ther 15:101-110. CrossRef Medline

McArthur JC, Steiner J, Sacktor N, Nath A (2010) Human immunodeficiency virus-associated neurocognitive disorders: mind the gap. Ann Neurol 67:699-714. CrossRef Medline

McCarty MF, Somcio RJ, Stoeltzing O, Wey J, Fan F, Liu W, Bucana C, Ellis LM (2007) Overexpression of PDGF-BB decreases colorectal and pancreatic cancer growth by increasing tumor pericyte content. J Clin Invest 117:2114-2122. CrossRef Medline

Mediouni S, Darque A, Baillat G, Ravaux I, Dhiver C, Tissot-Dupont H, Mokhtari M, Moreau H, Tamalet C, Brunet C, Paul P, Dignat-George F, Stein A, Brouqui P, Spector SA, Campbell GR, Loret EP (2012) Antiretroviral therapy does not block the secretion of the human immunodeficiency virus tat protein. Infect Disord Drug Targets 12:81-86. CrossRef Medline

Mermis J, Gu H, Xue B, Li F, Tawfik O, Buch S, Bartolome S, O’Brien-Ladner A, Dhillon NK (2011) Hypoxia-inducible factor-1 alpha/platelet derived growth factor axis in HIV-associated pulmonary vascular remodeling. Respir Res 12:103. CrossRef Medline

Nadal JA, Scicli GM, Carbini LA, Scicli AG (2002) Angiotensin II stimulates migration of retinal microvascular pericytes: involvement of TGF-beta and PDGF-BB. Am J Physiol Heart Circ Physiol 282:H739-H748. CrossRef Medline

Nakagawa S, Castro V, Toborek M (2012) Infection of human pericytes by HIV-1 disrupts the integrity of the blood-brain barrier. J Cell Mol Med 16:2950-2957. CrossRef Medline

Ramirez SH, Fan S, Dykstra H, Rom S, Mercer A, Reichenbach NL, Gofman L, Persidsky Y (2013) Inhibition of glycogen synthase kinase 3beta promotes tight junction stability in brain endothelial cells by half-life extension of occludin and claudin-5. PLoS One 8:e55972. CrossRef Medline

Ricardo-Dukelow M, Kadiu I, Rozek W, Schlautman J, Persidsky Y, Ciborowski P, Kanmogne GD, Gendelman HE (2007) HIV-1 infected monocyte-derived macrophages affect the human brain microvascular endothelial cell proteome: new insights into blood-brain barrier dysfunction for HIV-1-associated dementia. J Neuroimmunol 185:37-46. CrossRef Medline

Rumbaugh J, Turchan-Cholewo J, Galey D, St Hillaire C, Anderson C, Conant K, Nath A (2006) Interaction of HIV Tat and matrix metalloproteinase in HIV neuropathogenesis: a new host defense mechanism. FASEB J 20:1736-1738. CrossRef Medline

Shah GN, Morofuji Y, Banks WA, Price TO (2013) High glucose-induced mitochondrial respiration and reactive oxygen species in mouse cerebral pericytes is reversed by pharmacological inhibition of mitochondrial carbonic anhydrases: implications for cerebral microvascular disease in diabetes. Biochem Biophys Res Commun 440:354-358. CrossRef Medline

Silverman ES, Collins T (1999) Pathways of Egr-1-mediated gene transcription in vascular biology. Am J Pathol 154:665-670. CrossRef Medline

Stratman AN, Schwindt AE, Malotte KM, Davis GE (2010) Endothelialderived PDGF-BB and HB-EGF coordinately regulate pericyte recruitment during vasculogenic tube assembly and stabilization. Blood 116: 4720-4730. CrossRef Medline

Toborek M, Lee YW, Pu H, Malecki A, Flora G, Garrido R, Hennig B, Bauer HC, Nath A (2003) HIV-Tat protein induces oxidative and inflammatory pathways in brain endothelium. J Neurochem 84:169-179. CrossRef Medline

Toborek M, Lee YW, Flora G, Pu H, András IE, Wylegala E, Hennig B, Nath A (2005) Mechanisms of the blood-brain barrier disruption in HIV-1 infection. Cell Mol Neurobiol 25:181-199. CrossRef Medline

Westendorp MO, Frank R, Ochsenbauer C, Stricker K, Dhein J, Walczak H, Debatin KM, Krammer PH (1995) Sensitization of T cells to CD95mediated apoptosis by HIV-1 Tat and gp120. Nature 375:497-500. CrossRef Medline

Winkler EA, Bell RD, Zlokovic BV (2011) Central nervous system pericytes in health and disease. Nat Neurosci 14:1398-1405. CrossRef Medline

Xiao H, Neuveut C, Tiffany HL, Benkirane M, Rich EA, Murphy PM, Jeang KT (2000) Selective CXCR4 antagonism by Tat: implications for in vivo expansion of coreceptor use by HIV-1. Proc Natl Acad Sci U S A 97: 11466-11471. CrossRef Medline

Xu R, Feng X, Xie X, Zhang J, Wu D, Xu L (2012) HIV-1 Tat protein increases the permeability of brain endothelial cells by both inhibiting occludin expression and cleaving occludin via matrix metalloproteinase-9. Brain Res 1436:13-19. CrossRef Medline 
Yao H, Allen JE, Zhu X, Callen S, Buch S (2009) Cocaine and human immunodeficiency virus type 1 gp120 mediate neurotoxicity through overlapping signaling pathways. J Neurovirol 15:164-175. CrossRef Medline

Yao H, Yang Y, Kim KJ, Bethel-Brown C, Gong N, Funa K, Gendelman HE, Su TP, Wang JQ, Buch S (2010) Molecular mechanisms involving sigma receptor-mediated induction of MCP-1: implication for increased monocyte transmigration. Blood 115:4951-4962. CrossRef Medline

Yao H, Duan M, Buch S (2011a) Cocaine-mediated induction of plateletderived growth factor: implication for increased vascular permeability. Blood 117:2538-2547. CrossRef Medline

Yao H, Kim K, Duan M, Hayashi T, Guo M, Morgello S, Prat A, Wang J, Su TP, Buch S (2011b) Cocaine hijacks sigmal receptor to initiate induction of activated leukocyte cell adhesion molecule: implication for increased monocyte adhesion and migration in the CNS. J Neurosci 31: 5942-5955. CrossRef Medline
Yao H, Duan M, Yang L, Buch S (2013) Nonmuscle myosin light-chain kinase mediates microglial migration induced by HIV Tat: involvement of betal integrins. FASEB J 27:1532-1548. CrossRef Medline

Zechariah A, ElAli A, Hagemann N, Jin F, Doeppner TR, Helfrich I, Mies G, Hermann DM (2013) Hyperlipidemia attenuates vascular endothelial growth factor-induced angiogenesis, impairs cerebral blood flow, and disturbs stroke recovery via decreased pericyte coverage of brain endothelial cells. Arterioscler Thromb Vasc Biol 33:1561-1567. CrossRef Medline

Zhong Y, Zhang B, Eum SY, Toborek M (2012) HIV-1 Tat triggers nuclear localization of ZO-1 via Rho signaling and cAMP response element-binding protein activation. J Neurosci 32:143-150. CrossRef Medline

Zhou BY, Liu Y, Kim Bo, Xiao Y, He JJ (2004) Astrocyte activation and dysfunction and neuron death by HIV-1 Tat expression in astrocytes. Mol Cell Neurosci 27:296-305. CrossRef Medline 